\title{
ТЕХНОЛОГИЯ МАЛОЗАТРАТНОЙ ДОСТАВКИ ГРУЗОВ НА ЕСТЕСТВЕННЫЕ И ИСКУССТВЕННЫЕ СПУТНИКИ
}

\begin{abstract}
Аннотация. Исследование посвящено разработке малозатратной технологии транспортировки грузов с Земли на Луну, на другие космические объекты (такие как астероиды, спутники Марса и искусственные спутники) и в обратном направлении. Предметом исследования стали технологии доставки на Луну различных категорий грузов, технологии экспорта грузов с лунной базы на окололунную орбитальную станцию и околоземную орбитальную станцию, технологии передачи грузов с низкой околоземной орбиты на высокоэллиптические, технологии экспорта грузов с Земли на космические объекты искусственного и естественного происхождения. Целью работы является определение условий для устранения лишних операций и связанных с ними издержек и конструирования на этой основе малозатратных способов транспортировки, соответствующих достигнутому уровню развития техники и науки. Для решения поставленных задач применялись методы решения логистических задач. Для конструирования новых малозатратных способов транспортировки использовались методы «ТРИЗ» (теории решения изобретательских задач). В работе решена практически важная задача понижения стоимости доступа к космосу. Решение имеет мировую новизну, что подтверждено выдачей патентов СНГ, США, Евросоюза. Исследование показало, что при доставке на Луну определенных категорий грузов по разработанной технологии, получившей название «Моопtrap», стоимость доставки сокращается на 80 процентов, при использовании технологии экспорта лунного сырья, получившей название «Sattrap», транспортные затраты на создание комплекса «лунная база - лунная орбитальная станция» сокращаются на 80 процентов, при использовании технологии «Sattrap» в околоземном пространстве в 2-3 раза сокращаются затраты на доставку грузов со спутника на низкой орбите на топливную заправочную станцию на высокоэллиптической орбите.
\end{abstract}

Ключевые слова: лунная база, лунная орбитальная станция, внеземные ресурсы, переработка реголита, мягкая посадка, жесткая посадка, пенетратор, межорбитальный буксир, орбитальная топливозаправочная станция, недорогой доступ к космосу.

Abstract. The research is devoted to the development of a low-cost technology for transporting goods from Earth to the Moon, to other space objects (such as asteroids, Mars satellites and artificial satellites) and in the opposite direction. The subject of the study was the technology of delivering various categories of cargo to the moon, the technology of exporting cargo from the lunar base to the near-moon orbital station and the near-earth orbital station, technologies for transferring cargoes from low-earth orbit to highly elliptical, technologies for exporting cargoes from the Earth to space objects of artificial and natural origin. The purpose of the work is to determine the conditions for eliminating unnecessary operations and following expenses and designing on this basis low-cost transportation methods that correspond to the achieved level of development of technology and science. Methods of solving logistical problems were applied to reach the goals. To construct new low-cost methods of transportation, the methods of "TRIZ" (the theory of solving inventive problems) were used. A practically important task of lowering the cost of access to outer space has been solved in the study. The solution has a world novelty, which is confirmed by the issuance of patents of the CIS, the USA, the European Union. The research showed that when delivering certain categories of cargo to the Moon using the developed technology called «Moontrap», the shipping cost is reduced by 80 percent, according to the technology of export of lunar raw materials, called «Sattrap», the transportation costs for the creation of the "lunar base-lunar orbital station" are reduced by 80 percent, with the use of "Sattrap» technology in the near-Earth space, the cost of delivering goods from a satellite in low orbit to the fuel filling station on a highly elliptical orbit reduced by 2-3 times.

Keywords: lunar base, lunar orbital station, extra-terrestrial resources, regolith processing, soft / heavy landing, penetrator, orbital vehicle, orbital fueling station, low cost space access. 


\section{Исследования космоса 1(6) • 2018}

\section{Введение}

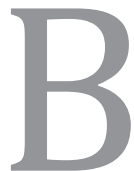

космической деятельности технологии доставки грузов в космос являются базовыми по отношению к прочим космическим технологиям. Критерием эффективности космической логистики является цена доставки груза на низкую околоземную орбиту (HOO) - в настоящее время эта цена очень высока и находится в диапазоне 10-20 тыс. долл./кг, при наличии отдельных предложений с более низкой ценой, в пределах 5-10 тыс. долл./кг. Доставка грузов на геостационарную орбиту (ГСО) и на Луну осуществляется по ценам в диапазоне от 25 до 50 тыс. долл./кг. Сегодня доставка на Луну 1 кг груза в 10-20 раз дороже, чем аналогичного груза на околоземную орбиту, а возвращение 1 кг груза с Луны обойдется в 30-50 раз дороже.

Эти цены задают высокий порог входа бизнеса в космическую деятельность. С 60-х годов прошлого века разработано множество проектов промышленного использования внеземного пространства - к этому располагают даровой высокий вакуум, длительная микрогравитация, легкость получения температур от близких к абсолютному нулю до $6000^{\circ} \mathrm{C}$, неограниченные запасы драгоценных, цветных и редкоземельных металлов, возможности создания солнечных электростанций с большой площадью и в 5-7 раз более эффективных чем на Земле, уникальные телекоммуникационные возможности для связи на Земле.

Из выше перечисленного рентабельной деятельностью стало только одно направление - эксплуатация телекоммуникационных спутников. Возможна коммерциализация другого направления промышленной деятельности - разработка ресурсов астероидов и Луны. Успех проектов создания внеземных рудников основан на том, что сверхдорогая доставка на астероиды перерабатывающего оборудования компенсируется производством продукции в сотни и тысячи раз большего по массе, чем завезенное оборудование, что на порядки сокращает издержки. Кроме того, по естественным причинам, возвращение продукции с астероидов в околоземное пространство на порядки проще и дешевле. Остальные направления космического бизнеса нуждаются в радикальном сокра- щении транспортных расходов. Очевидно, что такие сокращения требуют новых технических решений - ракетно-космический транспорт исчерпал ресурсы экономически оправданного совершенствования.

Недостатки ракетного транспорта хорошо понимали и отцы-основатели космонавтики и современные исследователи проблемы.

«Ракеты для меня только способ, только метод проникновения в глубину космоса, но отнюдь не самоцель, - объяснял Циолковский цель своих трудов. - Не спорю, очень важно иметь ракетные корабли, ибо они помогут человечеству расселиться по мировому пространству. И ради этого расселения в космосе я-то и хлопочу. Будет иной способ передвижения в космосе - приму и его...» $[1$, с. 21-22].

Вот описание ситуации академиком А. Коротеевым: «Мы имеем сегодня неэкономичные транспортные средства. Представьте, из каждых 100 тонн, улетающих с Земли, в полезную нагрузку, в лучшем случае, превращается 3\%. Это для всех современных ракет. Все остальное выбрасывается в виде сгоревшего топлива... Космонавтика, сегодня испытывает состояние, близкое к тому, в котором авиация оказалась после Второй Мировой войны, когда стало ясно, что с поршневыми двигателями уже невозможно ... иметь экономически выгодную авиацию. Тогда... в авиации произошел скачок, и от поршневых двигателей перешли к реактивным. Примерно та же ситуация сейчас в космической технике» [2].

Космонавт-испытатель Сергей Кричевский характеризует современное состояние ракетно-космического транспорта: «С научной точки зрения космическая ракета - это огромный «паровоз» с КПД всего 1-3\%, остальная же часть стартовой массы превращается в отходы, продолжая создавать проблемы для окружающей среды. Безальтернативный, чисто ракетный этап в развитии космической деятельности подходит к концу. А что придет ему на смену, зависит от нас. Надеюсь, совершенно новые технологии, которые изменят ... ситуацию» [3].

Разработка этих новых транспортных технологий ведется давно - с самого начала становления теории космических полетов. Разработан большой пакет предложений по сокращению затрат на доставку грузов в космос. Реализация 
некоторых из них приведет к радикальному сокращению транспортных издержек, что создаст основу космической экономики - рентабельной космической деятельности использующей в производственных целях даровые факторы и ресурсы внеземной среды.

\section{Основные предложения по сокращению транспортных издержек космической деятельности}

Недостатки ракетной техники привели к разработке группы проектов высокоэффективного космического транспорта, соответствующего задаче коммерциализации космической деятельности. К наиболее значащим относятся следующие проекты: электромагнитная катапульта для переброски лунного сырья в космическую ловушку грузов Дж. О`Нила; лунная ловушка земных грузов и орбитальная ловушка потоков грузов с Луны и Земли Э. Марвика; космические аппараты - накопители атмосферных газов Земли и Марса; станции производства ракетного топлива из марсианской атмосферы и лунной почвы, многоразовые ракеты-носители (PH).

Естественной реакций на недостатки ракетного вывода грузов с Земли стали планы транспортировать в околоземный космос необходимые грузы с тех небесных тел, которые имели лучшие условия для применения ракетного транспорта. Одним из таких небесных тел является Луна - благодаря слабому гравитационному полю лунные ракеты, аналогичные земным, могли бы доставлять на орбиту в десять раз больше грузов. Это улучшало экономические условия для создания космической промышленности.

Вместе с тем, применение ракет для экспорта лунных ресурсов как условия развития космической промышленности предполагало уже существование развитой промышленности на Луне - необходимо было иметь предприятия по производству ракетного топлива из лунных ресурсов, а также по изготовлению деталей и агрегатов для ракетной техники. Решение этой проблемы было найдено в виде проекта по использованию электромагнитных ускорителей, не требующих затрат ракетного топлива, для запуска грузов с Луны.
В 1962 г. Вильям Эшер, сотрудник NASA, исследовал подобную систему и присвоил ей название «Лунатрон» [4, с. 186]. Лунный ускоритель (катапульта) должен использовать принцип «волнового разгона», используемый в линейных электродвигателях. В условиях Луны с ее слабым гравитационным полем и в отсутствие сопротивления воздуха создание такой установки возможно. «Около половины массы электромагнитного пускового устройства рассматриваемого типа должна составлять масса энергетической установки. В пусковой комплекс будет включена обширная территория, занятая солнечными батареями, преобразующими энергию солнечного излучения в электричество. Принимая некоторые допущения относительно технических решений, можно подсчитать, что для запуска 100 кг полезного груза на окололунную орбиту потребуются оборудование массой 200 т и электростанция мощностью 11 МВт. Ускоритель длиной 1,1 км будет сообщать объекту ускорение около $130 \mathrm{~g}$, что выдвигает особые требования к прочности запускаемых грузов... Обогатительная фабрика и ускоритель указанных размеров могли бы обеспечить доставку на орбиту около 1000 т груза в год. Часть этого груза будет составлять жидкий кислород для заправки межорбитальных транспортных аппаратов, но основную долю составит сырье для орбитальных промышленных комплексов. На этом этапе капиталовложения в лунное поселение начнут давать коммерческий эффект» [5, с. 246-247].

Недостатком такого катапультного способа вывода грузов на окололунные орбиты является необходимость оснащения запускаемых контейнеров (снарядов) с грузом вспомогательными ракетными двигателями и системами управления полетом. Катапультный запуск выводит снаряды с грузами на эллиптические одновитковые орбиты, которые в переселении соприкасаются с Луной. По этой причине для перехода на многовитковую орбиту требуется второй импульс, который в данном случае должен сообщаться грузовому контейнеру ракетным двигателем. Это усложняет и удорожает транспортировку.

Сотрудник Принстонского университета Джерард О’Нил нашел решение проблемы избыточной сложности грузовых снарядов электромагнитной катапульты. Он предложил метать 


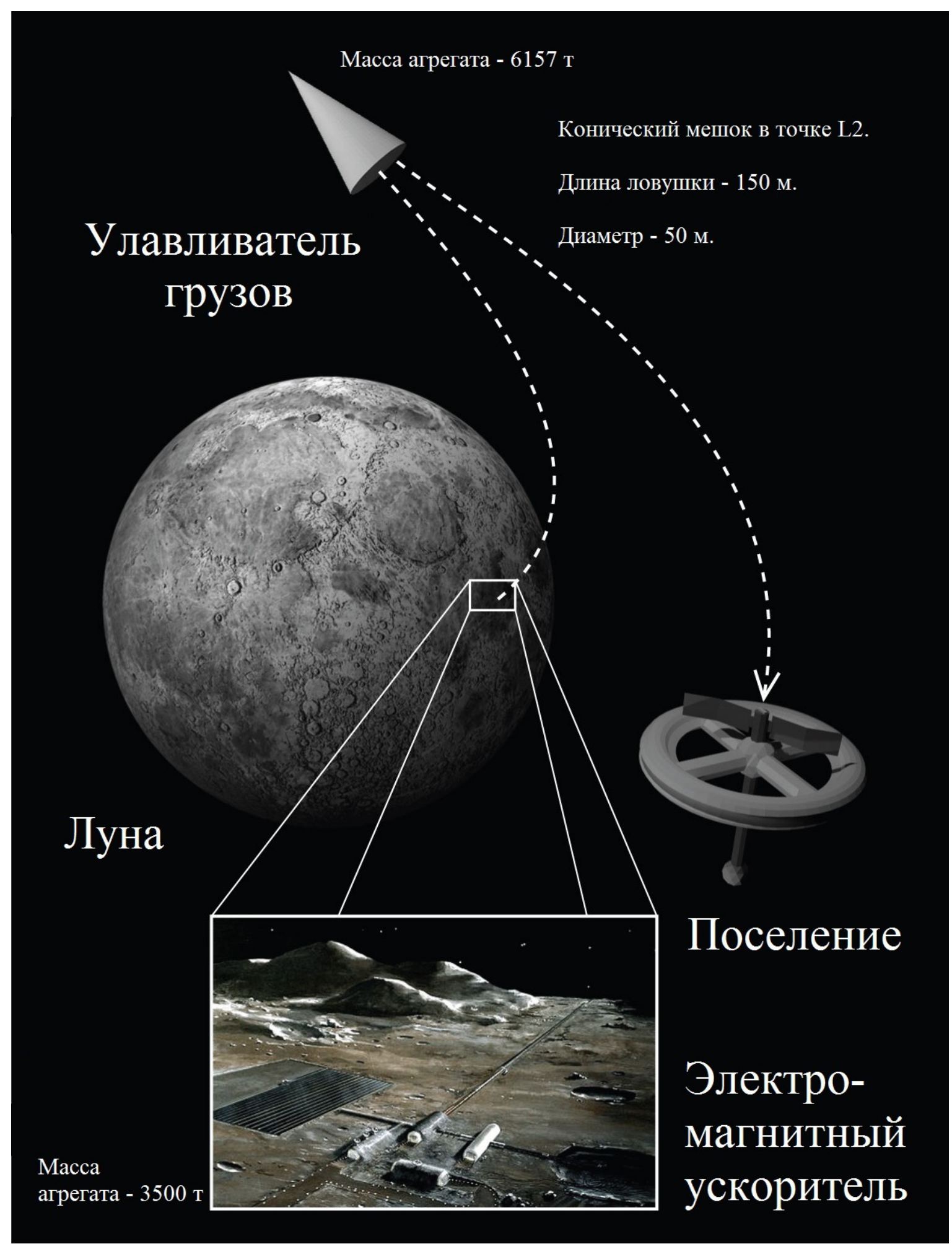

Рис. 1. Транспортная система Джерарда О’Нила 
порции грузов со второй космической скоростью в одну точку на лунном небе - в «либрационную точку» системы Земля - Луна, так как в ней можно динамически устойчиво поместить приемное устройство - ловушку для перехвата грузов (Рис. 1). В результате снаряды избавились от ракетных систем и приобрели вид прессованных кирпичей из реголита или простых оболочек с начинкой, что радикально сократило издержки. Однако, реактивный двигатель в итоге остался - его необходимо установить на ловушке грузов, но теперь он один на все запускаемые снаряды, при этом вместо термохимического двигателя на ловушке может применяться электрореактивный двигатель (ЭРД), имеющий высокий удельный импульс. Чтобы компенсировать количество движения, передаваемое ловушке потоком лунной породы, на его борту размещается электроядерная двигательная установка мощностью 25 МВт.

Вот некоторые основные параметры транспортной системы O'Нила. Для обеспечения электромагнитных ускорителей энергией потребуется разместить на поверхности Луны панели солнечных батарей общей площадью около 10 км² Электромагнитный ускоритель контейнеров с сырьем имеет массу - 3500 т. В течение года может выбрасывать с Луны 600000 т породы. Начальная скорость контейнеров-снарядов - 2,4 км/с. Масса снарядов - 20 кг. Посылки с Луны перехватываются в точке $\mathrm{L}_{2}$. Улавливатель грузов - конический мешок массой 6157 т, включая двигатели и ядерную энергоустановку и сам мешок массой 137 т. Длина мешка - 150 м. Диаметр - 50 м. Поперечные размеры ловушки достаточны, чтобы компенсировать неточность прицеливания полезных нагрузок, запускаемых с поверхности Луны электромагнитным ускорителем. Снаряды из прессованного реголита попадают в мешок со скоростью 300 м/с. Чтобы исключить разрушение ловушки, при ее бомбардировке образцами лунной породы, ее стенки защищены слоем реголита толщиной около 20 см. Чтобы обеспечить равномерность загрузки ловушки, ей придается постоянное вращение [6, с. 298-301].

Недостатком транспортной системы О'Нила является чрезмерно большая масса устройств, размещаемых на Луне - 3500 т и в космосе
- 6157 т. Очевидно, что такая индустриальная система для своей реализации сама нуждается в предварительной индустриализации Луны. Требуются иные решения задачи предварительной стадии промышленного освоения Луны - сокращение затрат на доставку грузов для строительства промышленной базы.

Искомое решение, близкое к требуемому, нашел американский исследователь Эдвард Марвик. Он разработал систему посадки на Луну грузов с Земли без использования ракетных посадочных ступеней. Решение в 3-5 раза сокращало затраты на доставку определенного типа грузов на Луну. Устройство представляет собой герметичную камеру в виде трубы, заполненную аэрозолями, с быстродействующим шлюзом на приемном отверстии. Грузовая капсула массой 1 т, имеющая диаметр до 1 м, после прохождения шлюза и дальнейшего движения по каналу с газами тормозилась от начальной скорости более 2400 м/с до нулевой (Рис. 2). Вместе с тем приемное посадочное устройство было избыточно массивным и крупногабаритным, а потому не могло быть доставлено с Земли. Длина устройства около 300 м при внутреннем диаметре 4 м и толщине 1-3 см стенок канала из железно-никелевого сплава. Масса такой конструкции доходит до 900 т, без учета вспомогательного оборудования. Соответственно таким массогабаритным характеристикам предполагалась изготовление посадочно-тормозной системы непосредственно на Луне из железно-никелевого сплава, выделяемого магнитной сепарацией из реголита. Таким образом, для реализации этой эффективной системы требовалась предварительное создание на Луне промышленных предприятий по производству металлов, формированию деталей и осуществлению монтажно-строительных работ.

Дополнительно к лунному посадочному устройству Э. Марвик разработал аналогичный околоземный транспортный комплекс-систему накопления земного вещества, поставляемого недорогими одноступенчатыми суборбитальными ракетами на ИСЗ за счет кинетической энергии лунных грузов [7, 8].

В его патентах US 4775120, US 5199671 решается проблема доставки в космос различных твердых материалов с Земли ударным ускоре- 


\title{
Исследования космоса 1(6) • 2018
}

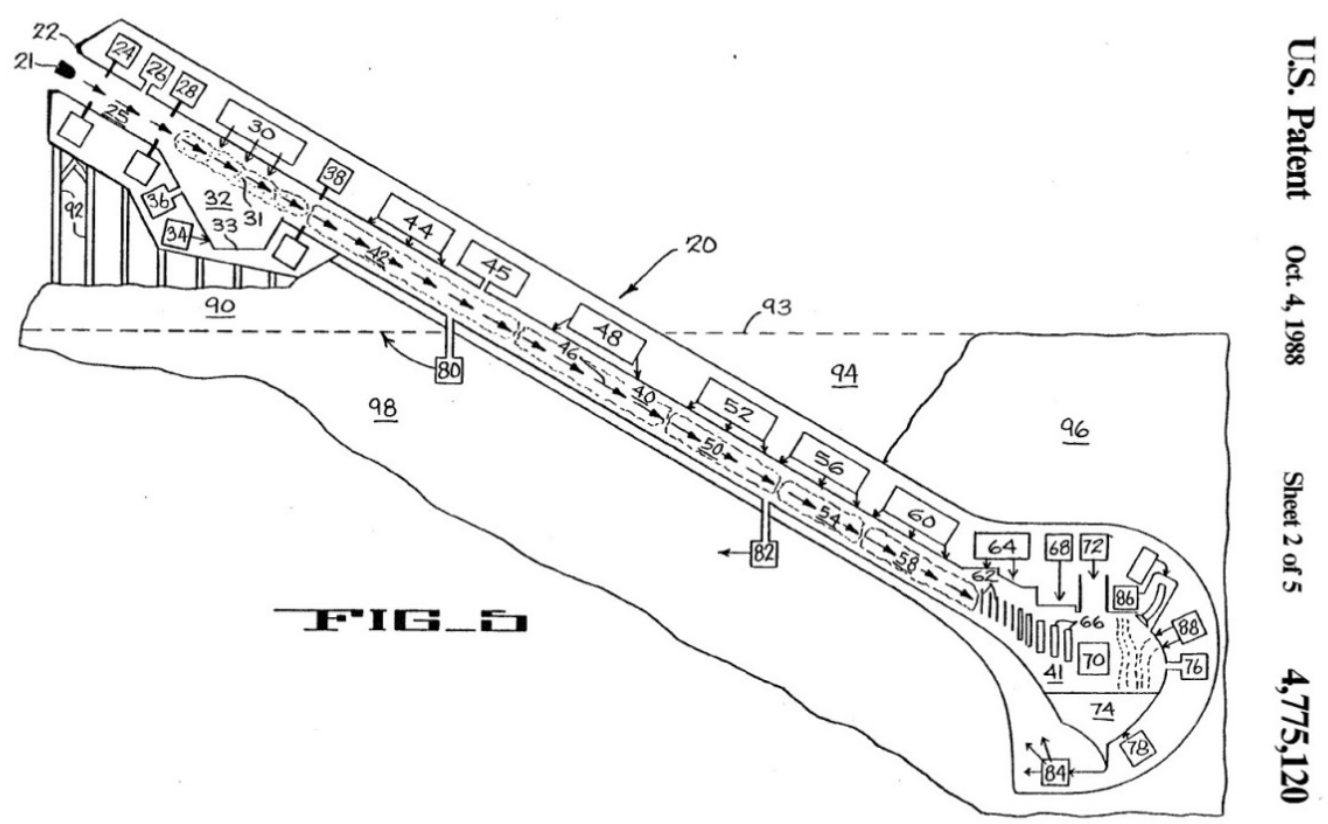

Pис. 2. Фигура 5 патента US4775120, где схематично представлено поперечное сечение длинной камеры лунного посадочного устройства и принцип безракетного торможения входящих грузовых капсул.

\begin{abstract}
Цифрой 21 обозначена капсула с грузом, на входе в канал тормозного устройства. Стрелками обозначен тормозной путь капсулы сквозь замедляющую движение газокапельную среду внутри канала.
\end{abstract}

нием за счет передаваемой неупругим ударом кинетической энергии грузов из лунных материалов. Порции лунного вещества посылаются космическими аппаратами, базирующимися на поверхности Луны и на орбитах в окололунном пространстве. В соответствии с содержанием вышеуказанных патентов США для приема грузов с Земли и с Луны используют массивный низкоорбитальный искусственный спутник. При посредстве спутника капсулы с лунным веществом производят передачу импульса движения от высокоскоростных лунных грузов низкоскоростным земным, поднимаемых ракетами зондирующего типа на высоту орбиты спутника. Поэтому вместо того, чтобы направлять ракету на высоту низкоорбитальной базы и разгонять ее до полного выравнивания скоростей, ракеты, используе- мые для вывода грузов описываемым способом, стартуют строго в вертикальном направлении, выпускают груз и падают вниз на Землю, с завершением падения мягкой посадкой, где проходят техническое обслуживание и используются повторно. Это позволяет использовать недорогие одноступенчатые суборбитальные ракеты с характеристической скоростью около 2-3 км/с вместо 9,5-10,5 км/с при использовании многоступенчатых ракет космического назначения.

Выпускаемый ракетами груз позиционируется таким образом, что он входит в отверстие крупной камеры, используемой для приема грузов, затем он внутри камеры сталкивается с большой массой вещества около центра камеры таким образом, что груз остается внутри камеры и стенки камеры остаются неповрежденными. 
Грузы с Земли со скоростью около 8 км/с посту пают через переднее входное отверстие камеры, а грузы лунного материала со скоростью около 11 $\kappa м / с$ поступают через заднее входное отверстие камеры с относительной скоростью около 3 км/с. Так как вектор-сумма моментов материалов, направляемых с Земли и направляемых с Луны, приблизительно равна нулю, благодаря правильному подбору масс, то высота и скорость спутника, используемого для получения грузов, остаются практически неизменными. Незначительно больший момент при получении грузов лунных материалов может компенсировать атмосферное сопротивление среды.

Эдвард Марвик конкретно показал, как, по сути, даровую потенциальную энергию, запасенную в лунном веществе, можно использовать для вывода грузов с Земли на околоземные орбитальные станции. Исключение из процесса транспортировки многоступенчатых ракет космического назначения сулило сокращение цен доставки в 10-20 раз. Однако, из-за некоторых принципиально неустранимых недостатков масса орбитальной части системы должна быть равна 40000 т, что делало проект невыполнимым без предварительной индустриализации околоземного космоса.

Еще ранее аналогичную спутниковую систему накопления земного вещества в виде атмосферных газов, а не твердых тел, разработал Стерж Деметриадес [9]. Достоинство системы состояло в достижимых массогабаритных характеристиках, что обеспечивалось аккумуляцией не твердофазных веществ, искусственно подаваемых с Земли, а накоплением остаточных атмосферных газов, которые естественным способом оказывались на пути спутника-коллектора.

Проект С. Деметриадеса известен под названием «PROFAC» (PROpulsive Fluid ACcumulator - аккумулятор жидкого топлива). Суть проекта состоит в том, что груз, в данном случае компоненты ракетного топлива, захватывается непосредственно из атмосферы. Аппарат «PROFAC» снабжен электроракетной двигательной установкой, в которой скорость истечения рабочего вещества превышает скорость вещества, поступающего из атмосферы. Таким образом, обеспечивается высокая доля полезного груза в общей массе поступающего воздуха из-за малой доли веществ, расходуемых в электроракетной двигательной установке. «PROFAC», перемещаясь по орбите, у границы плотных слоев атмосферы захватывает разряженный воздух, сжимает его путем газодинамического сжатия в заборнике и в компрессорах, охлаждает и выделяет жидкий кислород. Оставшийся азот «PROFAC» используют в ядерном электроракетном двигателе для компенсации потерь на аэродинамическое сопротивление. На высоте 100 км давление воздуха на входе в теплообменник накопителя очень низкое - порядка 8·10-4 бар, поэтому могут потребоваться дополнительные системы - нагнетатели (криокомпрессоры) или же адсорбционные и вымораживающие устройства. Способ, реализуемый в проекте «PROFAC», имеет преимущества перед доставкой топлива на орбиту при помощи термохимических ракет за счет того, что используются электроракетные двигатели (ЭРД), имеющие большой ресурс работы и низкую стоимость.

При тормозном импульсе в диффузоре равном 1 кг х 8000 м/с и ускоряющем импульсе ЭРД, равном 0,5 кг х 16000 м/с, на борту спутника-накопителя остается половина захваченных газов (без учета расхода рабочего тела на компенсацию других потерь скорости). По оценкам разработчиков использование подобной системы может в 10 раз снизить стоимость доставки на Луну. Следует отметить, что некоторые практические шаги по реализации подобной идеи предпринимались в СССР. В конце 60-х годов на борту экспериментальной ракеты «Янтарь» был испытан «воздушно-реактивный плазменный двигатель», способный компенсировать потери на аэродинамическое сопротивление на малой высоте. По сообщениям, двигатель имел такую же скорость истечения газов, как и двигатель «PROFAC» [5, с. $244 ; 10$, с. 206-210].

В СССР проект орбитального накопителя воздуха именовался «Воздушно-космический самолет с накоплением» или «ВКСН». В октябpe 1970 года на XXI конгрессе Международной астрономической федерации советские разработчики ВКСН доложили об испытаниях плазменно-ионного двигателя, работающего на азоте. Параметры двигателя соответствовали требованиям эксплуатации на ВКСН.

Не смотря на успехи в разработке спутниковых систем накопления кислорода и азота как 


\section{Исследования космоса 1(6) • 2018}

компонентов ракетного топлива, работы в этом направлении были остановлены. Эксплуатация разработанных орбитальных накопителей воздуха возможна только при использовании на борту спутников ядерных реакторов, что было сочтено недопустимым риском. Международные соглашения ограничили высоту полетов спутников с ядерными устройствами нижним пределом в 800 км, тогда как для эффективной аккумуляции воздуха «PROFAC» и «ВКСН» должны совершать полет на высотах минимум 120 км. В настоящее время, в связи с прогрессом лазерных систем передачи энергии, наблюдается ренессанс концепции применения спутников для аккумуляции воздуха. В перспективе энергоснабжение двигателей спутников-накопителей воздуха может осуществляться не за счет работы бортовых ядерных реакторов, а благодаря подводу энергии лазерным излучением в инфракрасном диапазоне [11].

В конечном итоге орбитальные коллекторы атмосферных газов, работающие за счет энергии подводимой извне лазерным излучением, будут реализованы. Период их внедрения придется на период реализации спутниковых солнечных электростанций (ССЭС). В планах разработчиков создание ССЭС гигаваттной мощности, использующей лазерное излучение для трансляции энергии на космические и наземные объекты [12]. На аккумуляцию 1 кг обогащенной кислородно-азотной смеси требуемая мощность двигательной установки орбитальных коллекторов воздуха составляет 256 МДж, при КПД равном $50 \%$. При мощности лазерного излучения ССЭС в 1 ГВт, транслируемого группировке орбитальных коллекторов воздуха, темп накопления воздуха составит 3,9 кг/с. За один год итог работы коллекторов - масса в 123000 т кислородно-азотной смеси $\left(\mathrm{O}_{2}-42 \%\right.$ и $\left.\mathrm{N}_{2}-58 \%\right)$. Таким образом, обеспечивается ресурсная база для производства ракетного топлива на орбите и снабжения сети заправочных станций в околоземном пространстве. На современном этапе для обеспечения текущих потребностей в заправках разгонных блоков (межорбитальных буксиров) на орбите требуется производство 200-250 т топлива в год. Такой объем производства обеспечивается ССЭС с мощностью генерируемого лазерного излучения в пределах 2-3 МВт.
В случае низких издержек производства ракетного топлива в космосе, стоимость полетов к Луне сократится в несколько раз. Вместе с тем, разработчики ССЭС указывают на необходимость использования лунных ресурсов для строительства ССЭС в целях сокращения капитальных затрат и обеспечения рентабельности их работы. В конечном итоге инновационный процесс зависят от создания промышленных баз на Луне, и, в свою очередь, создание лунных баз зависит от успешной реализации проектов ССЭС и орбитальных коллекторов воздуха - возникает замкнутый круг причин и следствий.

Разрыв этого круга требует длительного времени и дополнительных инноваций. Кроме того, существенный недостаток рассмотренной системы производства ракетного топлива на орбите - это ограниченный спектр химического состава сырья, получаемого из атмосферы. Для производства топлива для химических ракетных двигателей и рабочего тела для электроракетных двигателей требуются не только кислород и азот, но также водород, углерод, аргон и многое другое. Для производства на орбите конструкций и агрегатов космических аппаратов требуются различные металлы. Все эти вещества не могут доставляться на орбиту орбитальными накопителями воздуха.

Дополнительными инновациями, которые могут предшествовать внедрению технологий по использованию внеземных ресурсов могли быть разработки по созданию многоразовых ракет космического назначения (МРКН). Работы в этом направлении успешно идут в США - компания SpaceX неоднократно демонстрировала безударную посадку первых ступеней ракет космического назначения [13]. Вместе с тем, задача сохранения и повторного использования вторых (последних или орбитальных) ступеней далека от решения. Последняя ступень для возвращения с орбиты должна иметь массивную теплозащиту, что уменьшает долю полезного груза или даже полностью аннулирует возможность его размещения на многоразовой ступени. Создание МРКН с приемлемыми соотношениями масс теплозащиты и полезного груза требует увеличения массогабаритных характеристик ступени. В этом случае, как показали исследования компании SpaceX, стоимость большой 
МРКН резко увеличивает инвестиции в НИОКР до величины неприемлемой для инвесторов [14, 15]. Таким образом, сохраняется проблема радикального сокращения затрат на доступ к космосу. Требуются нестандартные решения. Такие решения дают технологии «Moontrap» и «Sattrap». В настоящее время технологии получали статус проектов НТИ [16].

\section{Технологии «Moontrap».}

Прототип технологии «Moontrap»- способ торможения грузов при доставке на Луну, предложенный Э. Марвиком в патенте US4775120. Здесь торможение осуществляется не за счет бортовых запасов топлива корабля, а за счет внешней газо-жидкостной среды, созданной на Луне искусственно и удерживаемой в герметичной камере, оборудованной быстродействующим шлюзом для пропуска корабля внутрь тормозной камеры. Таким способом выгодно доставлять грузы, способные выдерживать перегрузки в 1000 g. Благодаря тому, что на принимаемом грузовом аппарате масса груза не уменьшается за счет массы бортового запаса ракетного топлива, то масса груза может быть в 3-4 раза больше, чем на аппарате, реализующем способ мягкой посадки при торможении двигателями. Таким эффективным способом может доставляться большая часть грузов, необходимых для строительства и развития лунной базы. Способ сокращает транспортные расходы до 80\% - в этом его достоинство, но имеет серьезный недостаток - требует предварительных крупных затрат на доставку строительной техники, добывающего и металлургического оборудования для создания лунной тормозной системы.

Анализ возможного грузопотока для строительства и обслуживания лунной базы показывает, что больше 90\% грузов, представляют собой вещества и материалы, которые могут без вреда для своих свойств выдерживать ударные перегрузки и связанные с ними взрывное испарение и расплавление. Титан, алюминий, магний, бериллий - материалы необходимые для получения конструкционных сплавов для изготовления жилых и технологических модулей базы, деталей и агрегатов колесного и ракетного транспорта, - эти вещества без вреда способны выдерживать падение на лунную поверхность в диапазоне возможных скоростей от 2400 до 3300 м/с. Следовательно, для этой группы веществ будет излишним применение камеры с газожидкостной средой. Торможение металлических слитков-болванок возможно непосредственно в лунном грунте - реголите и скальной породе, то есть в теле самой Луны (Puc. 3). Поверхность Луны используется как естественная тормозная ловушка грузов, что дало основание назвать новый способ «Moontrap» $[17,18]$.

Новый способ торможения основан на технологии, которая была неоднократно апробирована при доставке грузов на Луну, - на использовании способа жесткой, или ударной посадки. Это доставка вымпела КА «Луна-2» и посадка таких ударных зондов, как серия КА Ranger, КА Lunar Prospector, SMART-1 и Chandrayaan-1. До сих пор способ не осознавался как реальная возможность сокращения затрат. Если решить проблему взрывного разлета вещества слитка при ударе, то такой способ станет самым выгодным среди известных способов доставки грузов на Луну - без всяких предварительных работ на поверхности Луны, болванки с металлическим сырьем будут доставлены в районы будущего строительства баз.

Проблема разброса вещества слитка имеет решение. Взрыв на поверхности исключается применением пенетраторов, - ударных проникающих зондов, которые изготовлены из транспортируемого металла или содержат доставляемое вещество в качестве начинки. Сильно удлиненная, стреловидная форма слитков металлов обеспечивает их проникновение в глубину грунта и взрывное испарение с образованием камуфлетов - замкнутых полостей в грунте без выбросов вещества на поверхность и образования воронки (Pис. 3-II). Испарение и плавление металлов в этих полостях не приводит к существенным потерям - после остывания конденсация происходит локализовано и доставленный груз может быть извлечен и использован для получения качестве конструкционных материалов.

Способ мягкого безударного прилунения заведомо неэффективен (Рис. 3-I). Масса космического аппарата (КА) на подлете к Луне перед началом торможения составляет около $33 \%$ от 


\section{Исследования космоса 1(6) • 2018}

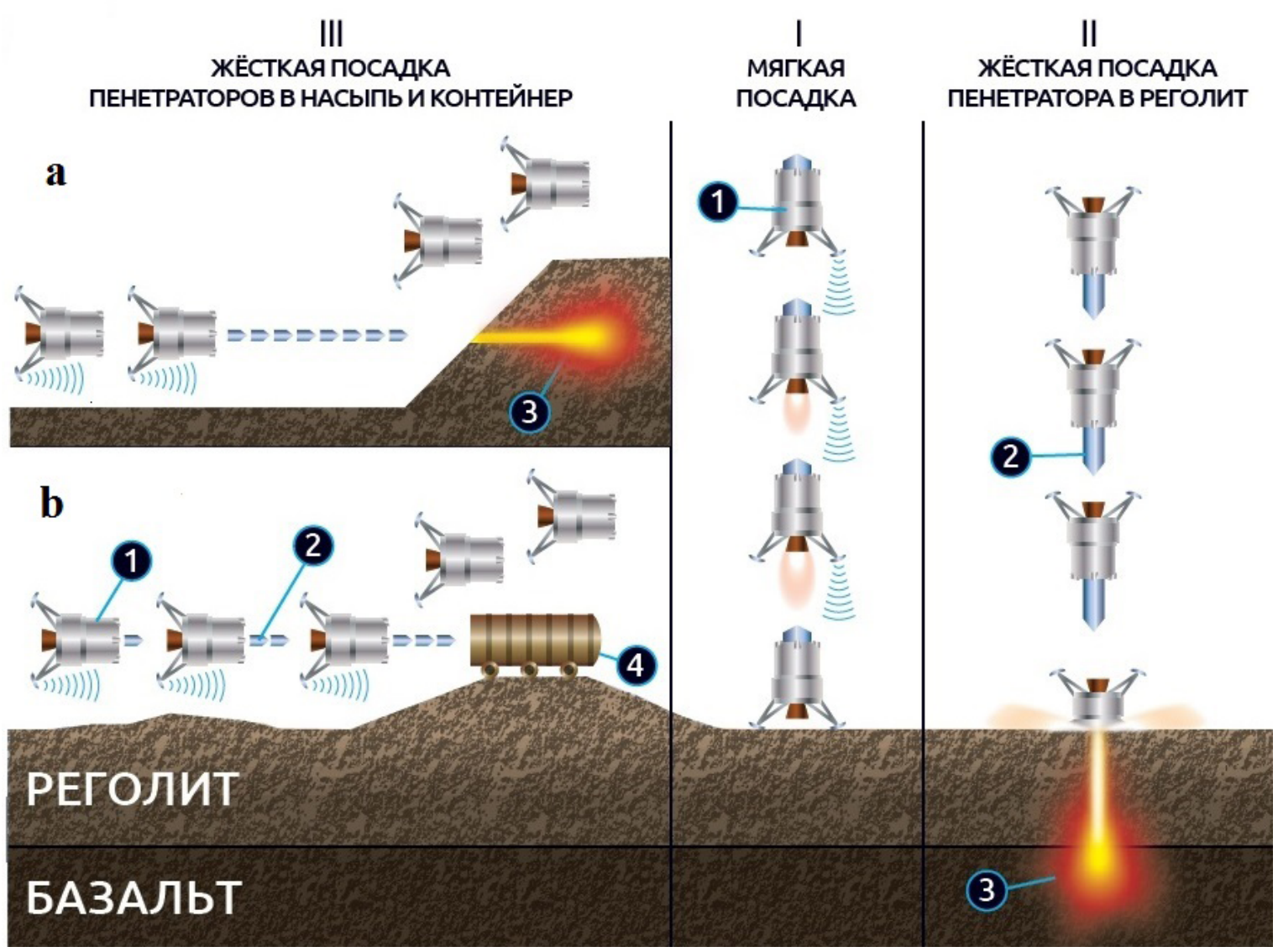

Рис. 3. Варианты прилунения.

I - Мягка посадка за счет торможения двигателями.

II - Жесткая посадка за счет торможения в реголите.

III - Жесткая посадка за счет торможения в искусственной насыпи из грунта и в герметизируемом контейнере с тормозной средой из реголита или других материалов.

1 - бустер (разгонный и/или разгонно-посадочный блок).

2 - пенетраторы (полезный груз).

3 - камуфлет (взрывная каверна с расплавом и паром из вещества груза).

4 - контейнер с тормозной средой на основе реголита, снабженный системой герметизации после поглощения пенетраторов.

его начальной массы на низкой околоземной орбите (HOO). После посадки доля полезного груза составляет около 5\% массы аппарата на НОO. К примеру, масса полезного груза КА «Луна-17» составила всего 13,5\% от массы КА перед началом торможения, масса полезного груза КА «Луна-21» - 14,7\%, а в проектируемом тяжелым посадочном КА, называемый Altair Lunar Lander, полезный груз может достичь в долевом соотношении $23,6 \%$. Таким образом, сегодня при доставке на Луну удается довезти от 15-ти до 25-ти процентов от массы, которая у посадочного модуля была первоначально накануне торможения. Следовательно, на участке подлета к Луне можно добиться увеличения массы грузов до 4 - 6 раз, а стоимость доставки при этом сократится от 75-ти до 85-ти процентов. Если же учитывать стоимость устраняемых посадочных ступеней, то экономия на участке торможения превысит $90 \%$ и в итоге общая стоимость доставки на Луну 
понизится с 10-кратной до 3-кратной стоимости доставки груза с Земли на НОО. При таких затратах, достижение Луны становится дешевле достижения околоземных астероидов в известных планах разработки их ресурсов.

Из камуфлетов металл извлекается при помощи стандартного оборудования лунной базы - экскавационных и транспортных механизмов. Современные проекты лунных баз предусматривают включение в состав базы землеройных машин для экскавации грунта и роверов для его перевозки, а также принтеров аддитивной

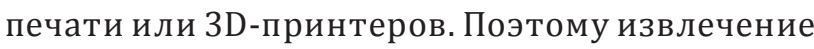
металла из-под слоя реголита значительно проще и дешевле мягкой посадки какого-либо металлического изделия с таким же весом. Масса данных механизмов может составлять всего 1\% от проектной массы базы, что не требует значительных расходов для их доставки на Луну способом мягкой посадки. Таким образом, большая часть конструкционных материалов - 99\%, необходимых для постройки базы, может быть доставлена с затратами в 3-4 раза меньшими.

Академик РАН Эрик Галимов по поводу перспектив аддитивной технологии на Луне констатирует: «С Земли есть смысл везти только то, что нецелесообразно делать на Луне: электронику, блоки управления. Это не так много весит. А вот титановый корпус хоть на 50 тонн там можно сделать автоматически - сегодня у нас есть 3D-принтеры. На Луне достаточно поставить солнечные батареи, чтобы получить нужную энергию для запуска производства» [19]. На этапе развертывания базы доставка сырья для 3D-принтеров с Земли на Луну по технологии «Moontrap» выгоднее производства сырья из реголита непосредственно на Луне:

1) производство алюминия из реголита требует 20 кВт.ч/кг, что в 180 раз больше энергии (398,4 кДж/кг), необходимой для расплавления готового алюминия, извлеченного из камуфлетов, производство титана - 30 кВт·ч/кг, что в 275 раз больше энергии (392,8 кДж/кг), необходимой для расплавления готового титана;

2) аннулируются затраты на доставку оборудования и реагентов, необходимых для переработки реголита - перерабатывающее оборудование изготавливается непосредствен- но на базе методом 3D-печати, включая новые 3D-принтеры;

3) запасы углерода, соединений хлора (хлориды некоторых металлов) и фтора (фторид калия) для химико-металлургических реакторов поставляются подобно металлам способом жесткой посадки - термическое разложение соединений на простые элементы, завершается образованием исходных соединений при остывании содержимого подлунной каверны.

В ряде районов Луны толщина реголита достигает нескольких метров. Так в Море Дождей, по данным исследований китайского лунохода Yutu, реголит залегает до глубины 3-5 метров, дальше идут коренные плотные породы [20]. Такой двуслойный пирог - удобный естественный коллектор для приема различных грузов методом жесткой посадки, так как плотные породы позволят концентрировать сбрасываемое вещество в камуфлете на заданной глубине реголита - 3-5 метров. С учетом того, что температура в глубине реголита отрицательна и постоянна (температура пород, залегающих на глубине 1 м, постоянна и равна $-35^{\circ} \mathrm{C}$.) в такой природный коллектор, кроме металлов, можно сбрасывать порции грузов на основе воды и тяжелыхуглеводородов. Диффундируя из раскаленного камуфлета в окружающие слои лунного промерзшего грунта пары воды и углеводородов подвергаются охлаждению и создают залежи сырья, удобные для извлечения и изготовления ракетного топлива. Реголит - хороший теплоизолятор и до нагрева верхних слоев теплом из камуфлета грунт с конденсатом может быть извлечен и переработан. Поверхность над будущим камуфлетом может быть заранее засыпана дополнительным слоем промерзшего реголита с поверхности окружающихучастков, температура которого в ночное время понижается до $-160{ }^{\circ} \mathrm{C}$. В районах с меньшей толщиной реголита придется создать насыпи, концентрируя грунт при помощи таких простых устройств как грунтометы, установленные на роверах. Используя насыпи удобно доставлять в район будущего строительства базы, прежде всего различные металлы и углерод и низколетучие жидкости (Puc. 3-III a).

Доставка жидких и высоколетучих веществ на лунную базу способом ударной посадки также возможна, но требует более сложной технологии 


\section{Исследования космоса 1(6) • 2018}

и использования вспомогательного оборудования - коллектора грузов, предварительно доставленного на Луну [21]. Коллекторы (ловушки) грузов - это легкие герметичные оболочки с быстродействующими приемными шлюзами для пропуска грузов-пенетраторов, заполненные рыхлой тормозной средой на основе реголита (Puc. 3-III b). Конструктивно коллектор представляет собой тонкостенную трубу, закрытую с торцов. Диаметр - 3,2 м, длина цилиндрической части 10-15 м. Масса оболочки - около 1 т, масса реголита - 80-100 т. Реголит гасит ударную волну и охлаждает газ. Оболочка в основном нужна для удержания газов, образующихся при взрывном испарении пенетраторов, содержащих воду, кислород или углеводороды. Благодаря оболочке доставленное вещество сохраняется в коллекторе и может быть перекачено в накопительные емкости.

Для доставки грузов используются пенетраторы массой 30-50 кг. Грузовые космические аппараты содержат пакет пенетраторов общей массой до нескольких тонн на каждый КА. Для передачи груза КА должны выходить на эллиптическую орбиту Луны с переселением над коллектором и сбрасывать по одному пенетратору каждый виток при подходе к коллектору. После сброса всей партии пенетраторов, КА выгодно возвращать на околоземную орбиту, то есть использовать в качестве многоразового межорбитального буксира. За счет небольшого разгонного импульса своих двигателей КА переходит на траекторию возвращения к Земле. В перигее орбиты на высоте ниже 100 км, используя многоразовый аэродинамический тормоз, буксир гасит избыток и при помощи корректирующего разгонного импульса переходит на HOO (Puc. 4), к примеру, на орбиту Международной космической станции (МКС). Прототипом такого многоразового буксира является буксир «Рывок», разработанный РКК «Энергия» [22]. Использование аппаратов, аналогичных буксиру «Рывок», должно понизить

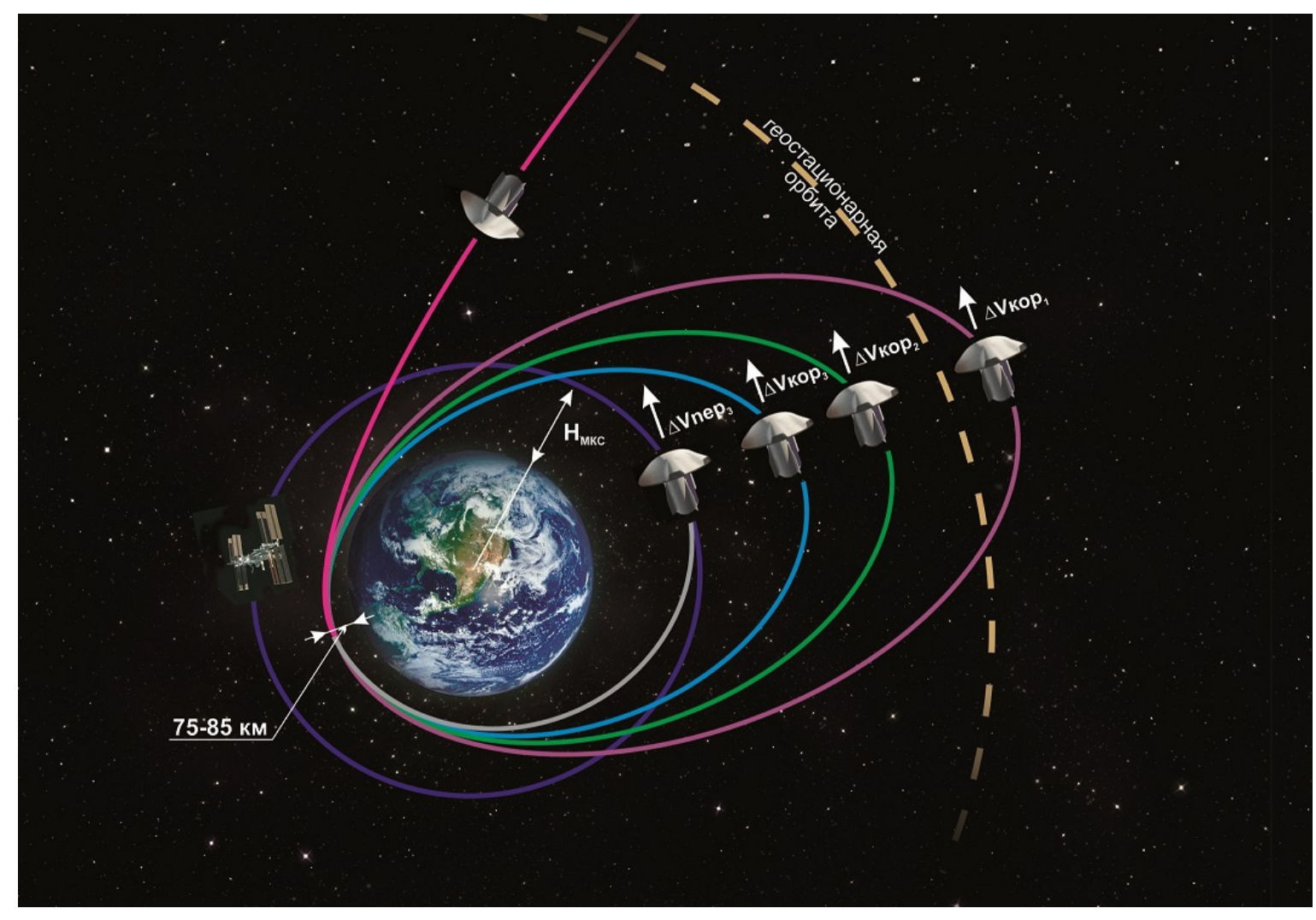

Рис. 4. Схема возвращения многоразового грузового КА с лунной орбиты на орбиту МКС на основе схемы работы многоразового межорбитального буксира «Рывок» РКК «Энергия». 
стоимость выхода на окололунную орбиту на 30 50 процентов и соответственно сократить затраты по всей цепочке транспортных издержек.

В качестве многоразовых буксиров для доставки пенетраторов возможно применение солнечных и ядерных межорбитальных электроракетных буксиров, разрабатываемых РКК «Энергия» [23].

Существует еще один способ сократить массогабаритные характеристики лунных коллекторов. В проекте Э. Марвика решается задача быстрой остановки порции груза массой около 1 т. В проекте «Moontrap» эта избыточная задача устраняется и в этом его главное отличие. Порция груза подается в коллектор не одномоментно вся сразу, а постепенно - в виде непрерывного единого или дискретного потока вещества. В этом случае при поглощении равной порции груза масса приемного устройства сокращается более чем в 10 тыс. раз. Поток в коллектор создается цепью из небольших пенетраторов длиной несколько тысяч метров. Трубки, заполненные транспортируемым веществом такой же длины также удобны для применения. Такие треки разворачиваются КА вдоль траектории полета незадолго до столкновения с коллектором. Настоящее решение признано имеющим абсолютную новизну, что закреплено выдачей патента США US 8882047 B2 и патента Евросоюза ЕР 2390188.

При такой схеме подачи вещества имеет значение не столько масса оболочки коллектора, сколько тормозная среда в качестве аккумулятора тепла. Масса среды получается больше массы оболочки коллектора. Если в качестве аккумулятора тепла в коллекторах применять твердофазные вещества при соблюдении определенных пропорций с поглощаемым веществом, то испарения вещества груза не происходит - вещество наполнителя ловушки и груза переходят из твердого состояния в жидкое. Масса тормозной среды, исключающая испарение: алюминий - 8 кг на 1 кг пенетратора из алюминия; титан - 8 кг на 1 кг пенетратора из титана; литий - 7,5 кг на 1 кг пенетратора из лития; водяной лед - 9,5 кг на 1 кг пенетратора из водяного льда. Таким образом, для захвата типичной порции массой в 50 кг в виде цепи из капсул-пенетраторов требуются коллекторы с массой тормозной среды от 400 до 500 кг, что позволяет обойтись без реголита в качестве тормозной среды. Благодаря малой начальной массе они могут быть доставлены на Луну даже методом мягкой посадки.

Побочные эффекты взаимодействия доставляемых веществ и реголита, применяемого в качестве тормозной среды, будут способствовать сокращению стоимости снабжения базы конструкционными металлами, например железом, а также водой и кислородом. При поглощении грузов-пенетраторов, содержащих углерод, метан, водород или другие активные вещества, в коллекторе начнутся восстановительные реакции (при соответствующем подводе теплоты). Результатом поглощения порции груза станет образование дополнительных продуктов.

По расчетам РКК «Энергия», удельная стоимость доставки полезного груза на Луну с помощью разгонного блока с ЖРД типа «ДМ» (по данным 2011 г.) составила 52000 долл./кг [24, с. 528]. Соответственно, обратный полет с Луны на Землю корабля с экипажем будет дороже в 4-6 раз, то есть будет иметь удельную стоимость 200-300 тысяч долл./кг, что экономически препятствует созданию обитаемой лунной базы. Технология «Mоontrap» устраняет этот барьер, так как в 3 раза сокращает затраты на поставки ракетного топлива и обеспечивает взлетно-посадочные модули ракетным топливом по цене около 17000 долл./кг.

В перспективе цены сократятся с 17 000долл./кг до 460 долл./кг: технология «Moontrap» выгодно сочетается с технологиями обработки углеродом и водородом обогащенного магнитной сепарацией реголита, в результате чего получаются металлы для 3D-принтеров и сырье для производства ракетного топлива - углекислый газ и вода. Например, подача водорода в коллектор с лунным ильменитом при температуре $300^{\circ} \mathrm{C}$ на 1 кг водорода дает почти 28 кг железа и 9 кг воды. Таким образом, выход продукции составляет 37 кг, что эквивалентно доставке груза на Луну в среднем по цене 460 долл./кг (17 000 долл./37 кг =460 долл./кг). Это в 10-20 раз меньше нынешних цен доставки грузов на НОО. Последующая переработка сырья в компоненты топлива и металлический порошок (и/или проволоку) для 3D-принтеров дает лишь незначительное удорожание. Таким образом, снимаются нынешние финансовые ограничения на создание обитаемой 


\section{Исследования космоса 1(6) • 2018}

лунной базы. Возможные отпускные цены этой продукции - 1000-2000 долл./кг.

В качестве тормозной среды не обязательно применять только реголит. Если в коллекторах применять ранее доставленные вещества (титан, алюминий, магний, литий, воду) в качестве тормозной среды, запасы которых растут, то в коллекторах изначально накапливаются чистые вещества, не нуждающиеся в очистке от примесей из реголита. Сохраняется первоначальная чистота передаваемого материала. К примеру, при приеме ловушкой груза в виде алюминия в качестве тормозной среды используются гранулы из алюминия, при приеме воды - гранулы льда, при приеме порции углерода или углеводородов - гранулы углерода.

Грузовой КА на основе разгонного блока «ДМ» (в различных модификациях) за 100 оборотов вокруг Луны забросит в такой специализированный коллектор груз общей массой 5 т. Полученного груза достаточно для заполнения тормозной средой десяти малых коллекторов или одного большого. Оболочки новых коллекторов доставляются с Земли способом мягкой посадки, а в последующем изготовляются методом каменного литья из реголита и/или способом аддитивной печати. При большой частоте использования безреголитных коллекторов потребуется решение проблемы быстрого отвода тепла от тормозной среды. Решение этой задачи не представляет особой сложности на поверхности Луны, в отличие от сброса тепла в открытом космосе.

При низких ценах на конструкционные материалы и ракетное топливо, которые обеспечивает технология «Moontrap», лунная промышленная база способна стать рентабельным поставщиком материалов для создания различных объектов на геостационарной (ГСО) и других околоземных орбитах (текущие цены на вывод объектов на ГСО доходят до 50000 долл./кг). Мировой рынок пусковых услуг по выводу КА на околоземные орбиты вырос почти до 6 млрд. долл./год, а мировой рынок производства КА колеблется в диапазоне - 10,7-16,6 млрд. долл./год [25, с.50]. Поэтому, даже без учета роста спроса на топливо со стороны компаний, начинающих разработку ресурсов астероидов, создание базы на Луне по технологии «Moontrap» станет рентабельным предприятием.

\section{Технология «Sattrap». Луна-ИСЛ.}

Технология «Moontrap» является частью более широкой технологии «Sattrap», которая позволяет обеспечить экономную доставку грузов с поверхности Луны на окололунную орбитальную станцию. Технология «Sattrap» показывает второй путь сокращения затрат на создание комплекса из базы и орбитальной станции.

Так же как Луна является ловушкой для захвата пенетраторов посылаемых с Земли, так же и спутник Луны подходят на роль ловушки грузов, бросаемых с суборбитальной скоростью с Луны. Естественные спутники Луны неизвестны, поэтому в качестве орбитальной ловушки может использоваться только искусственный спутник Луны (ИСЛ). Такой ИСЛ конструктивно представляет собой контейнер с реголитом или иной тормозной средой и должен иметь определенные массогабаритные характеристики и вспомогательные устройства. Контейнер с реголитом может выполнять функцию ловушки грузов на окололунной орбите так же успешно, как и на поверхности Луны. Применение сателлитов в качестве ловушки отражено в названии способа - технология «Sattrap».

Относительно поглощаемых порций груза масса ИСЛ недостаточно велика, чтобы не претерпевать практически значимых изменений скорости. ИСЛ будет испытывать торможение при захвате грузов, что требует оснащения его межорбитальным буксиром для компенсации потерь скорости. Часть вещества, поглощаемого буксиром, после извлечения из тормозной среды и обработки расходуется как рабочее тело электроракетных двигателей для компенсации тормозного импульса при столкновении с грузами-пенетраторами. Остаток порции образует собственно полезный груз, экспортированный с Луны на окололунную станцию. Порции грузов подаются в орбитальную ловушку суборбитальными ракетами или механическими катапультами, например, выполненных по схеме классических грунтометов и пескометов (Рис. 5). На первом этапе развития коллекторной системы экспорта сырья на орбитальную станцию массы подаваемых порций реголита должна быть минимальной, чтобы сократить массогабаритные параметры агрегатов находящихся на 
Луне. Величина порции может составлять 10 кг. Скорость метания в точку перехвата также может быть невелика - меньше 100 м/с. Соответственно скорость порции относительно коллектора будет меньше 1680 м/с.

При тормозном импульсе коллектора, равном 10 кг х 1680 м/с, компенсирующий импульс ЭРД может быть равен 1 кг х 16800 м/с. Остаток груза - 9 кг. Малый расход рабочего тела (РТ) дает возможность использовать некоторые компоненты реголита в качестве РТ электроракетного двигателя. Например, суммарное содержание магния и кальция в реголите $12,5-16,5 \%$, что позволяет использовать их в качестве РТ наряду с другими компонентами. В РКК «Энергия» испытывался электроракетный двигатель с литиевым рабочим телом мощностью 500 кВт, на котором были получены вполне удовлетворительные характеристики [26]. Замена лития на магний (содержание в реголите 4,6-5,8\%) или кальций $(7,9-10,7 \%)$, добываемые на лунной базе, не приведет к заметному ухудшению тяговых и энергетических характеристик, так как потенциалы ионизации этих металлов близки.

Могут применяться буксиры, как с фотоэлектрическими преобразователями, так и с ядерными источниками энергии. Для использования солнечной энергии подходят тонкопленочные солнечные батареи с центробежной стабилизацией. На борту ТГК «Прогресс» проведены первые успешные эксперименты с высокоэффективными бескаркасными центробежными солнечными батареями с удельной мощностью до 2,5 кВт/кг [27]. Такие батареи имеют низкую стоимость и массу из-за отсутствия каркаса, высокую плотность укладки и возможность переориентации на гироскопическом принципе без затрат рабочего тела.

Для использования ядерной энергии подходят реакторы из советского космического наследия - «Эльбрус-400/200». Вырабатываемая мощность в форсированном режиме 400 кВт, в номинальном режиме 200 кВт. Время работы: до полугода в форсированном режиме; до 20 лет в номинальном режиме. Полная масса: 7000 кг. Тепловая мощность реактора в номинальном режиме 2 МВт [28]. Этот бонус может выгодно использоваться для переработки реголита и создания литых каменных корпусов промышленных блоков орбитальной станции. Использование лития в качестве теплоносителя между реактором и 3D-принтером снимает проблемы с радиационным облучением сырья.

Принципиально важно - на орбитальную станцию выгодно передавать не готовую продукцию, полученную в результате переработки реголита, а сам реголит. В этом варианте обеспечивается экономия на доставку химико-металлургических модулей на поверхность Луны. Запуск промышленных модулей станции с Земли на окололунную орбиту в 3-4 раза дешевле доставки модулей на поверхность Луны. Таким образом, лунный орбитальный коллектор (ловушка грузов и буксир) решает проблему малозатратного создания промышленного комплекса.

В плоскости орбиты коллектора в связи с баллистическими особенностями траектории его движения необходимо размещать две катапульты реголита. Одна в переселении, другая в апоселении. Катапульту в переселении выгодно размещать в районе низменности с ровным дном - в лунном море. Катапульту в апоселении соответственно размещать на возвышении - одном из лунных плато. Поскольку на обратной стороне Луны расположены наиболее высокие плато, с высотами до 2,5 км, то апоселений коллектора следует проектировать на этой стороне. При таком расположении расстояние по высоте между катапультами и коллектором будет минимальным, что упрощает процесс подачи порций реголита в точку перехвата. Выбирая оптимальное соотношение между массой коллектора и перехватываемой порций реголита можно так подобрать изменения орбиты, что расстояния точек перехвата от первой и второй баз будут минимальны.

В настоящее время создание орбитальной станции дешевле создания лунной базы, но без производства ракетного топлива и конструкционных материалов из лунных ресурсов станция абсолютно бесполезна. А лунная база решает задачу производства топлива, но имеет начальные затраты превышающие бюджетные лимиты. Орбитальный коллектор реголита снимает проблему. На поверхность Луны необходимо доставить только немассивное оборудование по сбору реголита и установку типа грунтомета или пескомета для подачи частиц реголита, в точку 


\section{Исследования космоса 1(6) • 2018}

встречи с коллектором в моменты его пролета над базой. Все прочее наиболее массивное оборудование размещается на орбите возле обитаемой станции без стыковки с ней, по варианту «станция-облако».

Производство ракетного топлива на орбите из обогащенного реголита проще в энергетическом аспекте - фрагменты реголита, поступающие в ловушку на скорости 1680 м/с, испытывают тормозной нагрев (1,4 МДж/кг). При термическом воздействии ильменит разлагается на железо и кислород или, при добавлении водорода, железо и воду. Поэтому для разложения сырья потребуется незначительная добавка тепла.

Цена доставки груза в орбитальный коллектор (ловушку и буксир) в основном определяется амортизацией оборудования в расчете на единицу груза. Расчет цены производится по приближенной формуле:

$$
Ц_{\ni}=\frac{\left(Ц_{д}+Ц_{и}\right) \cdot M_{K}+Ц_{\text {эду }} \cdot W_{\text {эду }}}{T \times M_{\Gamma}},
$$

где $Ц_{\ni}$ - цена экспорта или доставки груза на орбитальный коллектор, $Ц_{д}-$ уд. стоимость

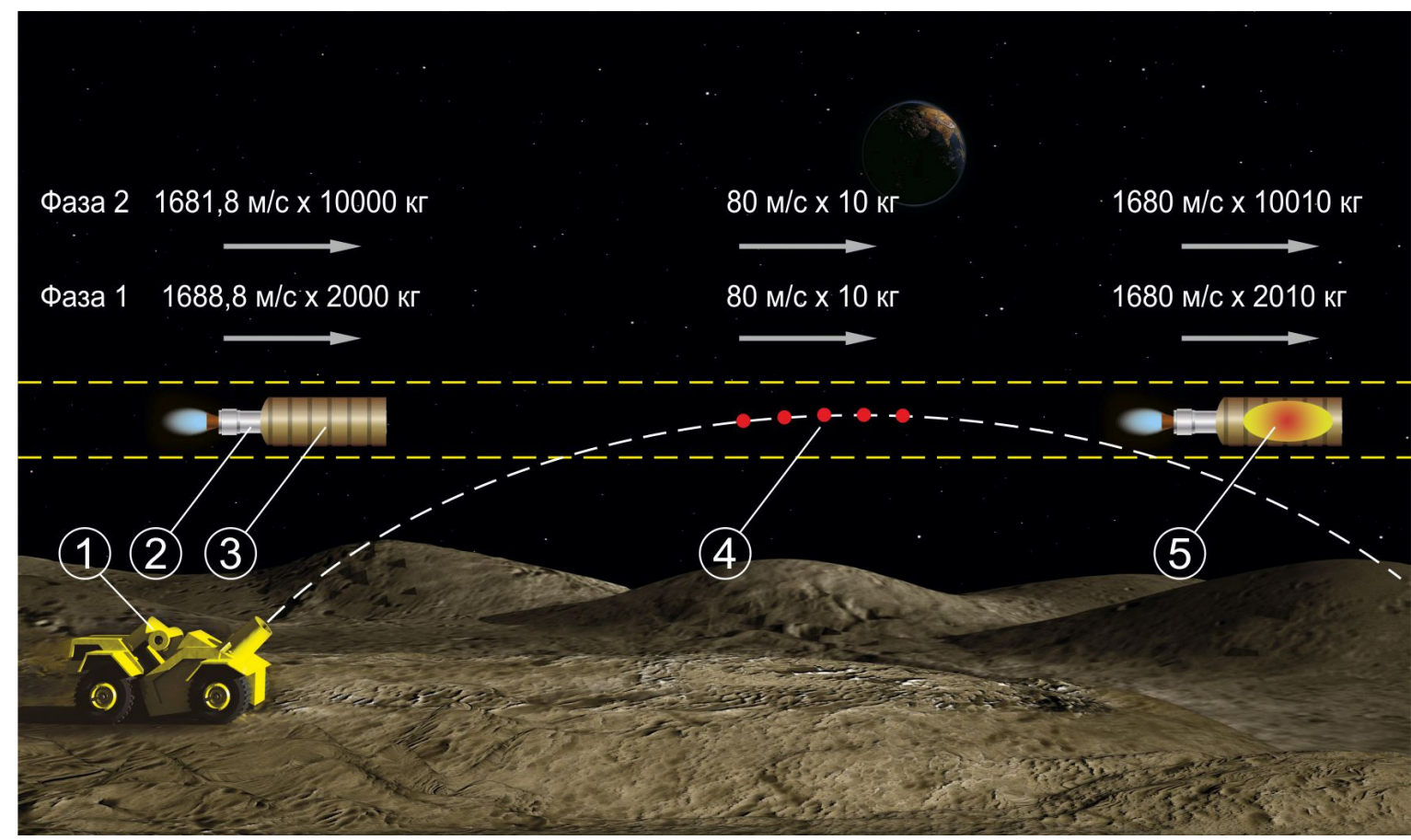

Рис. 5. Технология передачи порций реголита в лунный орбитальный коллектор

1 - самодвижущийся комплекс с агрегатами собирания и метания реголита в точку встречи с орбитальным коллектором.

2 - часть орбитального коллектора - межорбитальный буксир.

3 - часть орбитального коллектора - контейнер-ловушка с реголитом

4 - порции реголита в точке перехвата коллектором

5 - зона накопления порций реголита внутри контейнера-ловушки.

Фаза 1 - начальный период аккумуляции лунного вещества при минимальной массе тормозной среды из реголита. Начальная масса коллектора - 2000 кг. Период необходим для увеличения массы тормозной среды в целях улучшения баллистики процесса.

Фаза 2 - начальный период промышленной эксплуатации орбитального коллектора. Начальная масса коллектора - 10000 кг. Возможно дальнейшее попутное наращение массы коллектора за счет реголита. 
доставки оборудования с Земли на орбиту ИСЛ, $Ц_{и}$ - уд. стоимость изготовления оборудования, $M_{K}$ - масса конструкции коллектора, $Ц_{\text {эду }}$ - уд. стоимость энергодвигательной установки, $W_{\text {эду }}$ - мощность энергодвигательной установки, $T$ - рабочий ресурс оборудования, $M_{\Gamma}$ - масса грузов доставленного на ИСЛ в течение года.

Цена доставки груза на орбитальный коллектор $Ц_{\ni}$ будет равна 390 долл./кг при следующих условиях: цена доставки оборудования на окололунную орбиту $Ц_{д}$ равна 35 тыс. долл./кг; цена изготовления конструкции коллектора $\bigsqcup_{и}$ - 15 тыс. долл./кг; масса коллектора $M_{K}-2000$ кг;
$Ц_{\text {эду }}-50$ тыс. долл./кВт, $W_{\text {эду }}-43,5$ кВт (стоимость энергодвигательной установки $\bigsqcup_{\text {эду }} \mathrm{x} W_{\text {эду }}=2,172$ млн. долл.); рабочий ресурс коллектора $T$ - 3 года; масса экспортированного груза в течение 1 года - 87300 кг (4850 оборотов/год х 2 захвата/оборот порции груза в 9 кг - 10 кг за вычетом 1 кг в качестве РТ ЭРД).

Цена экспорта груза на орбиту $Ц_{\ni}$ снижается, когда методами 3D-печати на орбите изготовляется новый коллектор из лунных материалов. При уменьшении только одного параметра $Ц_{д}$

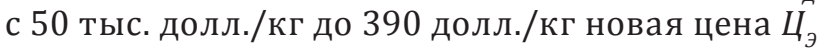
у нового коллектора снизится с 390 долл./кг до

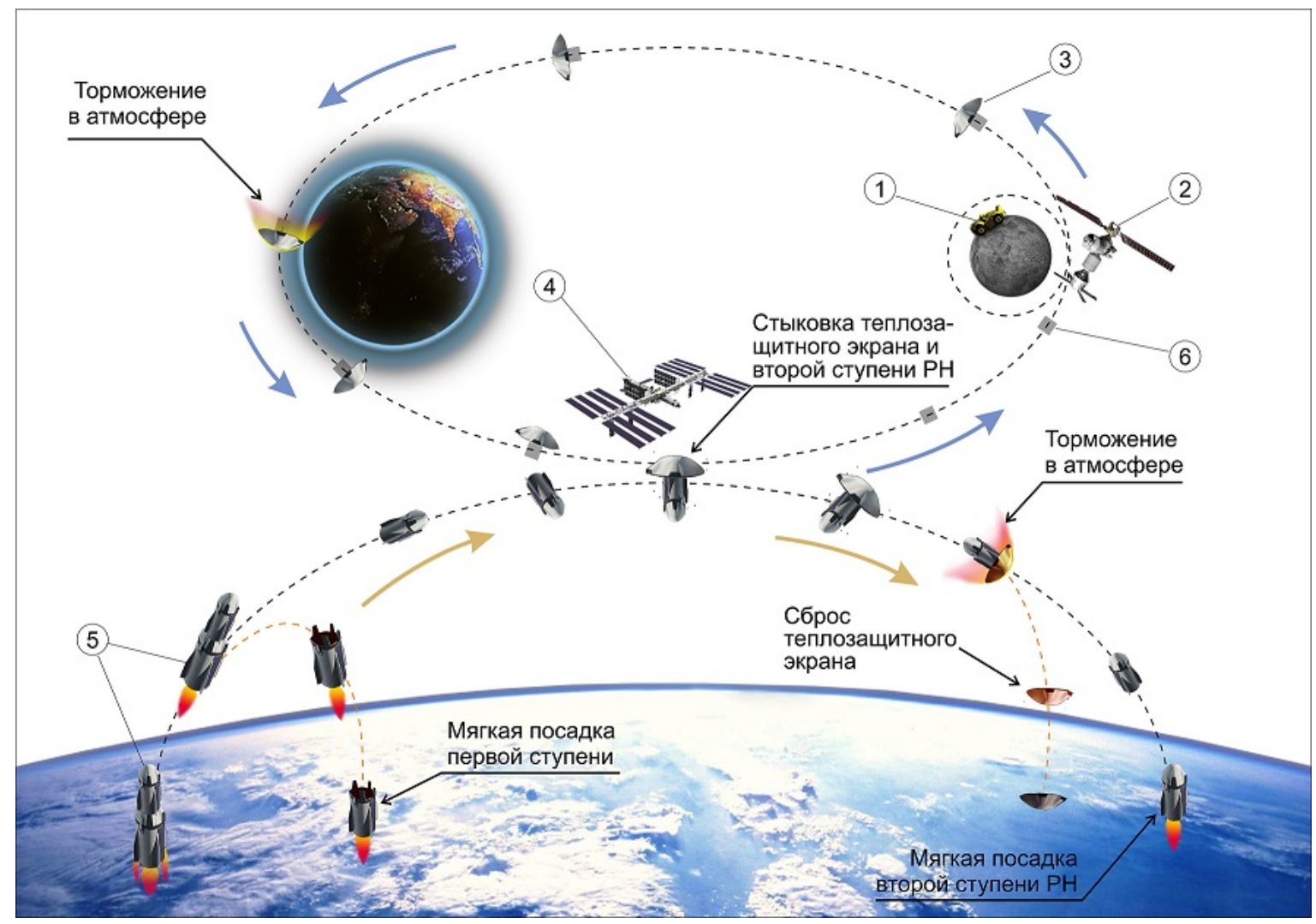

Рис. 6. Технология спасения орбитальной (последней) ступени РН за счет теплозащитных аэродинамических тормозных экранов из лунных ресурсов и создания полностью многоразовой космической транспортной системы

1 - лунная база (ЛБ) в виде самоходного комплекса из сборщика реголита и катапульты

2 - лунная орбитальная станция (ЛОС) в виде комплекса из пилотируемого модуля и модулей переработки реголита и производства теплозащитных экранов

3 - теплозащитный экран с межорбитальным буксиром

4 - международная космическая станция (МКС)

5 - двухступенчатая многоразовая $Р \mathrm{PH}$

6 - межорбитальный буксир 


\section{Исследования космоса 1(6) • 2018}

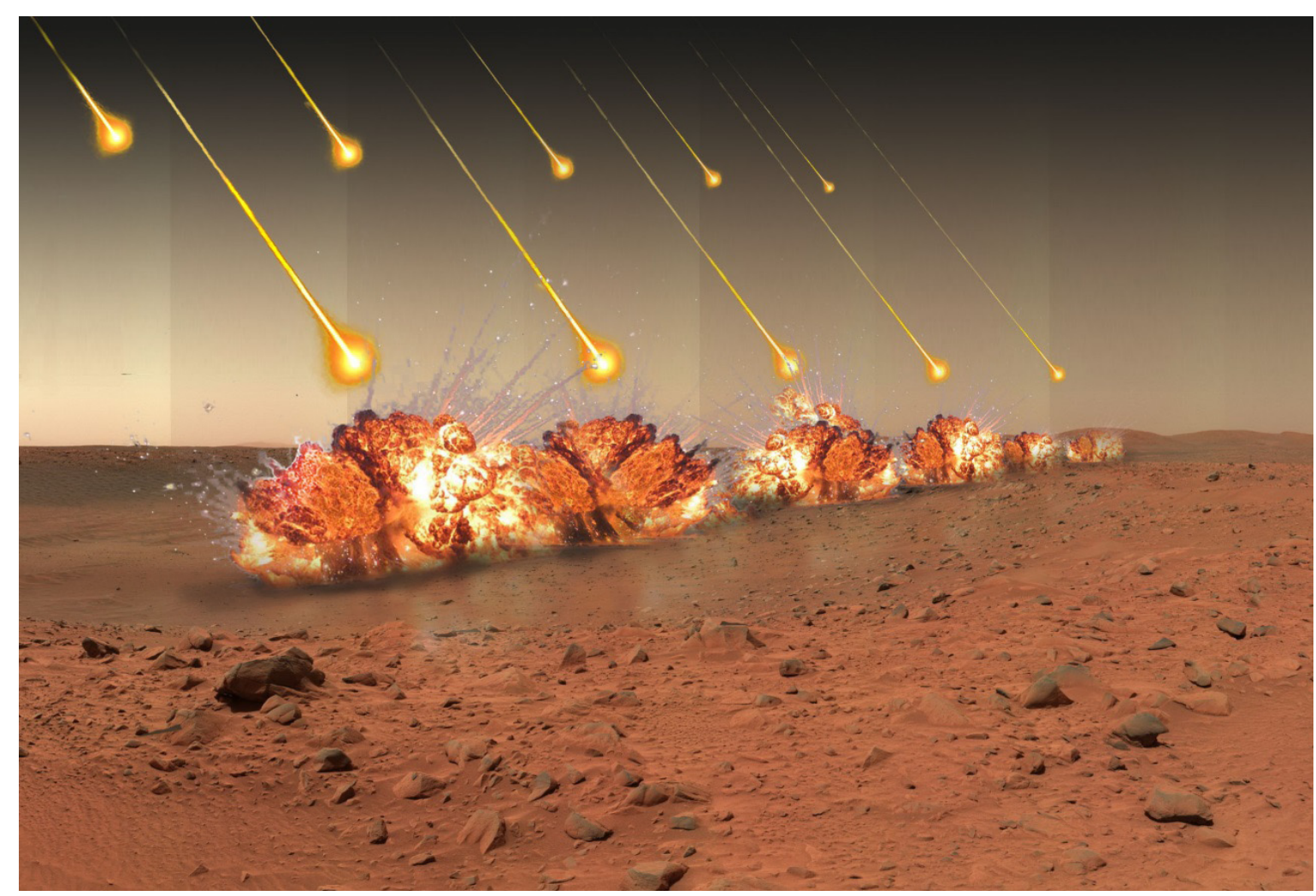

Рис. 7. Прокладка каналов в Сахаре. Использование запасов кинетической энергии лунных минеральных ресурсов для мелиоративных работ в пустынях планеты

126 долл./кг. Изменение параметра $Ц_{и}$ с 15 тыс. долл./кг до 1000 долл./кг, допустимое в условиях производства агрегатов коллектора на орбите,

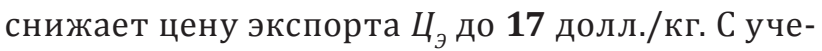
том сокращения других стоимостных показателей, возможных при дальнейшем развертывании технологии «Sattrap», цена экспорта грузов на ИСЛ сократится до $\mathbf{1}$ долл./кг. Такое радикальное сокращение цен создает возможность для реализации группы проектов по добыче редкоземельных и ряда цветных металлов даже для нужд земной промышленности, так как рыночные цены этих товаров находятся в диапазоне от нескольких долларов до сотен долларов за килограмм.

Большие потоки больших масс недорого сырья с Луны на станцию решают также проблему защиты экипажа от радиации на орбите. Из реголита и продуктов его переработки создаются защитные антирадиационные экраны. Засыпать жилые блоки трехметровым слоем реголита те- перь можно не только на поверхности Луны, но и непосредственно на орбите - за 3 года работы коллектора первого поколения масса аккумулированного реголита составит $262 \mathrm{~T}$.

Изобилие недорого сырья открывает новые направления коммерциализации лунного промышленного комплекса. Важным направление работы станции станет производство из реголита одноразовых теплозащитных экранов для спускаемых с околоземных орбит КА и ступеней ракет (Рис. 6). В настоящее время сложно обеспечить многоразовое использование последних ступеней ракет-носителей (РН). Недорогие теплозащитные оболочки, доставляемые с окололунной станции на НОО, обеспечат возвращения последних (орбитальных) ступеней РН и их повторное использование.

Задача сохранения и повторного использования последних или орбитальных ракетных ступеней далека от решения. Последняя ступень для возвращения с орбиты должна иметь 
массивную теплозащиту, что уменьшает долю полезного груза или даже полностью аннулирует возможность его размещения на многоразовой ступени. Создание возвращаемых орбитальных ступеней с приемлемыми соотношениями масс теплозащиты и полезного груза требует увеличения массогабаритных характеристик ступени, что в настоящий период неприемлемо по бюджетным причинам. Следовательно, использование теплозащиты из недорогого лунного сырья - один из реальных способов создания полностью многоразовых РН на базе уже используемых в космической деятельности и одновременно сокращения затрат на полеты к Луне и астероидам.

Другим перспективным направлением коммерциализации лунного промышленного комплекса (ЛОС и ЛБ) станет проведение взрывных экскавационных работ на Земле за счет кинетической энергии пенетраторов - ударников из лунного материала (Рuc. 7). До подписания договоров о запрещении испытаний ядерного оружия США планировали использовать ядерные заряды в горном деле, создания бухт-ковшей на морском побережье, строительства каналов и т.п. по программе «Plowshare» («Плуг»). Аналогичные проекты были созданы и реализованы в СССР [29]. Вместе с тем, наряду с правовым ограничением использования мирных ядерных взрывов и негативных экологических последствий, их применение ограничено избыточной мощностью.

В этом аспекте, пенетраторы из лунного материала, использующие чистую кинетическую энергию (около 50 МДж/кг), при невысоком тротиловом эквиваленте порядка 1000 т, могли бы эффективно использоваться в горном деле, строительстве каналов, искусственных водохранилищ и морских портов.

\section{Технология «Sattrap». Межорбитальная транспортировка}

Следующим этапом развития технологии «Sattrap» станет производство на окололунной орбите новых орбитальных ловушек грузов и межорбитальных буксиров. Часть этих систем будет переводиться с окололунной орбиты на околоземные орбиты. На первом этапе используются стандартные лунные орбитальные ловуш- ки. При диапазоне типичных для Луны скоростей перехвата груза в 1500-2000 м/с орбитальные ловушки грузов эффективны для передачи грузов, например, компонентов топлива, от ИСЗ, находящихся на HOO, на ИСЗ, находящиеся на высокоэнергетических орбитах.

В качестве примера рассмотрим систему из двух ИСЗ: первый ИСЗ расположен на НОО, второй ИСЗ, представляющий собой коллектор грузов (ловушку с буксиром), расположен на высоко эллиптичной орбите. Орбиты синхронизированы. Для удобства рассмотрения примем, что период обращения коллектора равен 6 часам, а период ИСЗ, передающего грузы, равен 1,5 часа. Высота НОО в данном случае - 282,5 км. Параметры орбиты коллектора - перигей на высоте 282,5 км и апогей на высоте 20504,2 км. Встреча коллектора с передающим грузы низкоорбитальным ИСЗ в перигее происходит каждые 6 часов с относительной скоростью 2060 м/с (Рис. 8).

В качестве грузопередающего ИСЗ может использоваться грузовой блок, выведенный на полуторачасовую орбиту традиционной ракетой космического назначения («Союз-2», «Зенит-2» или «Протон»). Груз блока - сырье для получения компонентов ракетного топлива и/или сырье для космического 3D-принтера, например, в виде ленты, намотанной на бобину.

Груз передается на коллектор следующим способом: лента вытягивается из блока и далее под действием сил трения с остаточным воздухом в окружающем пространстве, расправляется в виде шлейфа, тянущимся за блоком. Масса ленты - 10 кг. В перигее орбитальный коллектор, двигаясь по траектории, совпадающей с траекторией движения ленты, догоняет ленту и поглощает ее с относительной скоростью около 2000 м/с. Время поглощения - 10 с. При поглощении ленты сила торможения, действующая на коллектор - 2000 Н. Необходимая для компенсации тормозного импульса тяга двигателя за счет большего времени работы в 10-20 раз меньше. За счет многократных встреч общая масса передаваемого груза составляет 14600 кг за год или 1200 кг за месяц. Компенсация аэродинамического сопротивления двигателями коррекции потребует расход около 100 кг топлива химических ЖРД за год обращения грузового блока по низкой орбите или 8 кг за месяц. 


\section{Исследования космоса 1(6) • 2018}

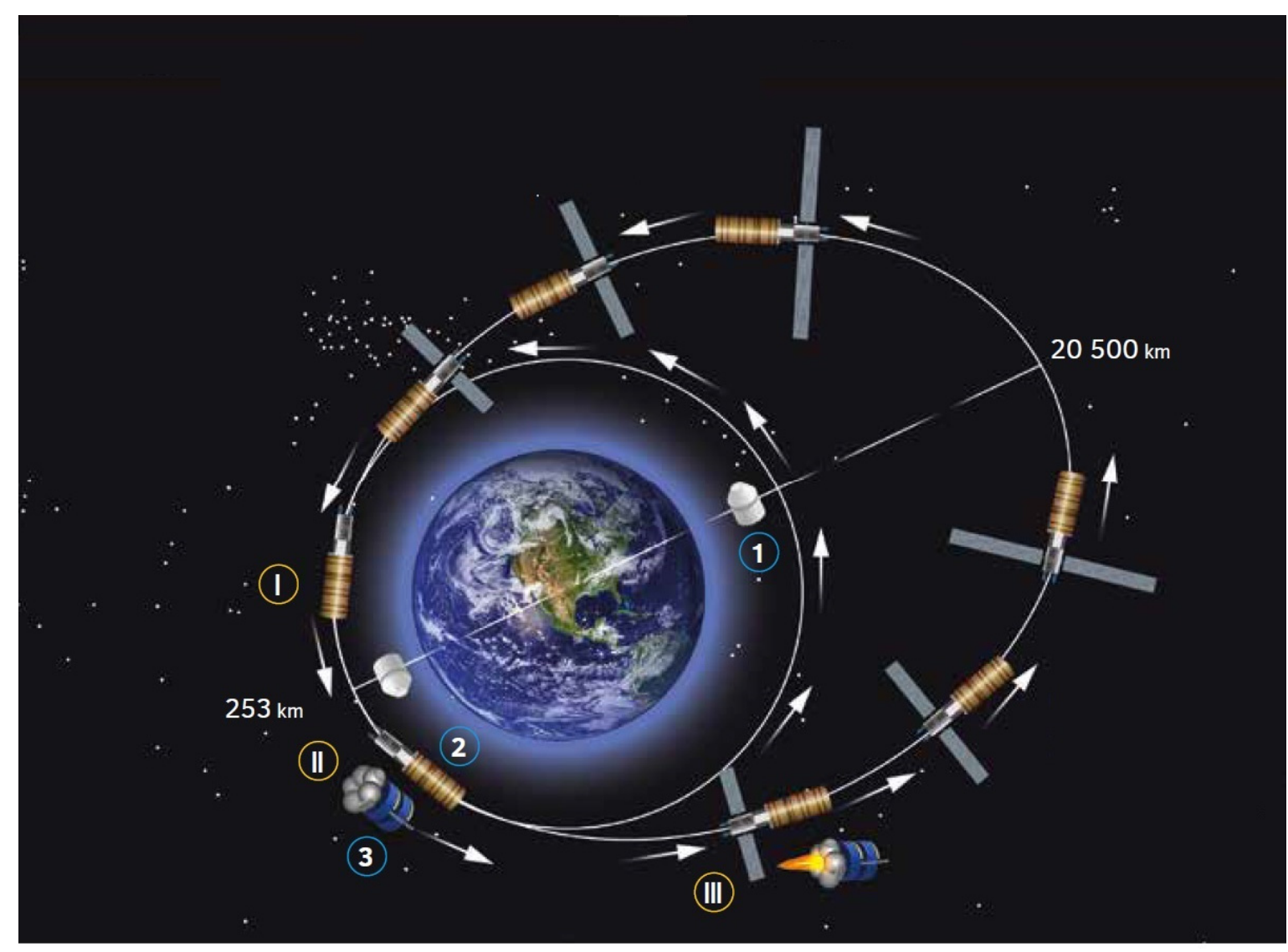

Рис. 8. Передача топлива в коллектор на ВЭО и дозаправка разгонного блока.

1 - грузовой блок с запасом топлива на НОO

2 - депо топлива и коллектор компонентов ракетного топлива: ловушка и буксир с СТРд

3 - разгонный блок

I - фаза передачи в перигее порции груза от грузового блока в орбитальную ловушку

II - фаза дозаправки разгонного блока во время его стыковки в перигее с топливным депо

III - фаза продолжения ускорения разгонного блока за счет новой порции топлива

Показаны этапы развертывания и свертывания тонкопленочных солнечных батарей после и до захвата порций груза

Тормозной импульс ловушки компенсируется работой солнечного теплового ракетного двигателя (СТРД), использующим водород в качестве РТ. Близкий по параметрам СТРД разработан ФГУП «Исследовательский центр им. М.В. Келдыша». Время работы ЖРД находится в диапазоне от 10 до 200 с, что снижает требование к силе тяги ЖРД до 10 Н. Имеющиеся в России разработки такого двигателя обеспечивают скорость истечения РТ до 8000 м/с. Благодаря модернизации удельный импульс двигателя может быть поднят до 9000 м/с. Таким образом, за счет более высокого импульса, требующего почти двукратного сокращения РТ, увеличатся масса груза, переносимого на высокоэнергетические орбиты, переходные на пути к геостационарным и лунным станциям.

Стоимость передачи компонентов ракетного топлива по этой технологии составит 2,2 тыс. долл./кг. Расчеты производя тся по формуле (1).

Цена доставки груза на орбитальный кол-

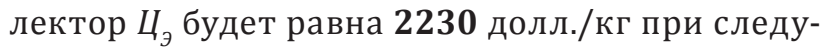
ющих условиях: цена доставки оборудования на околоземную орбиту $Ц_{д}$ равна 5 тыс. долл./кг; цена изготовления конструкции коллектора $Ц_{и}$ 


\section{Космонавтика}

- 15 тыс. долл./кг; масса коллектора $M_{K}-2000$ кг; $Ц_{\text {эду }} 50$ тыс. долл./кВт, $W_{\text {эду }}-440$ кВт (при КПД равном 0,8 и удельном импульсе равном 8000 м/с); рабочий ресурс коллектора $T-5$ лет; масса экспортированного груза в течение 1 года - 11388 кг (1460 оборотов/год х 1 захват/оборот порции груза в 7,8 кг - 10 кг за вычетом 2,2 кг в качестве РТ СТРД).

Тормозной импульс ловушки компенсируется работой солнечного теплового ракетного двигателя (СТРД), использующего водород в качестве РТ. Близкий по параметрам СТРД разработан ФГУП «Исследовательский центр имени М. В. Келдыша» [30-33]. СТРД защищен патентами РФ №2126493, №2145639, №2150054, №2176767, №2197630.

В настоящее время цена вывода КА с НОO на ВЭО традиционными ракетно-космическими технологиями составляет 15-30 тыс. долл. США. Эти транспортные издержки могут сокращены. Теперь, грузовые КА, направляемые к Луне, вместо скорости около 3000 м/с должны набирать меньшую скорость, равную 1500 м/с, что дает увеличение полезной нагрузки в несколько раз, затем стыкуются в перигее с коллектором, выполняющим функцию заправочной станции, заправляют топливные баки и продолжают полет к Луне, добирая оставшуюся часть скорости. Цена топлива в этих 03С на ВЭО превышает цену вывода на НОO всего на 2230 долл./кг. Аналогично через дозаправку выгодно осуществлять доставку КА на ГСО.

\section{Технология «Sattrap». Земля-ИСЗ}

Следующий этап использования потенциала комплекса ЛБ-ЛОС - создание орбитальных коллекторов для эксплуатации на околоземных орбитах. Благодаря низкой стоимости поставок реголита и производства лунных конструкционных материалов, на НОО создаются коллекторы, для улавливания грузов многоразовых суборбитальных ракет-носителей (МСРН) с относительной скоростью до 7800 м/с (Рuc. 9).

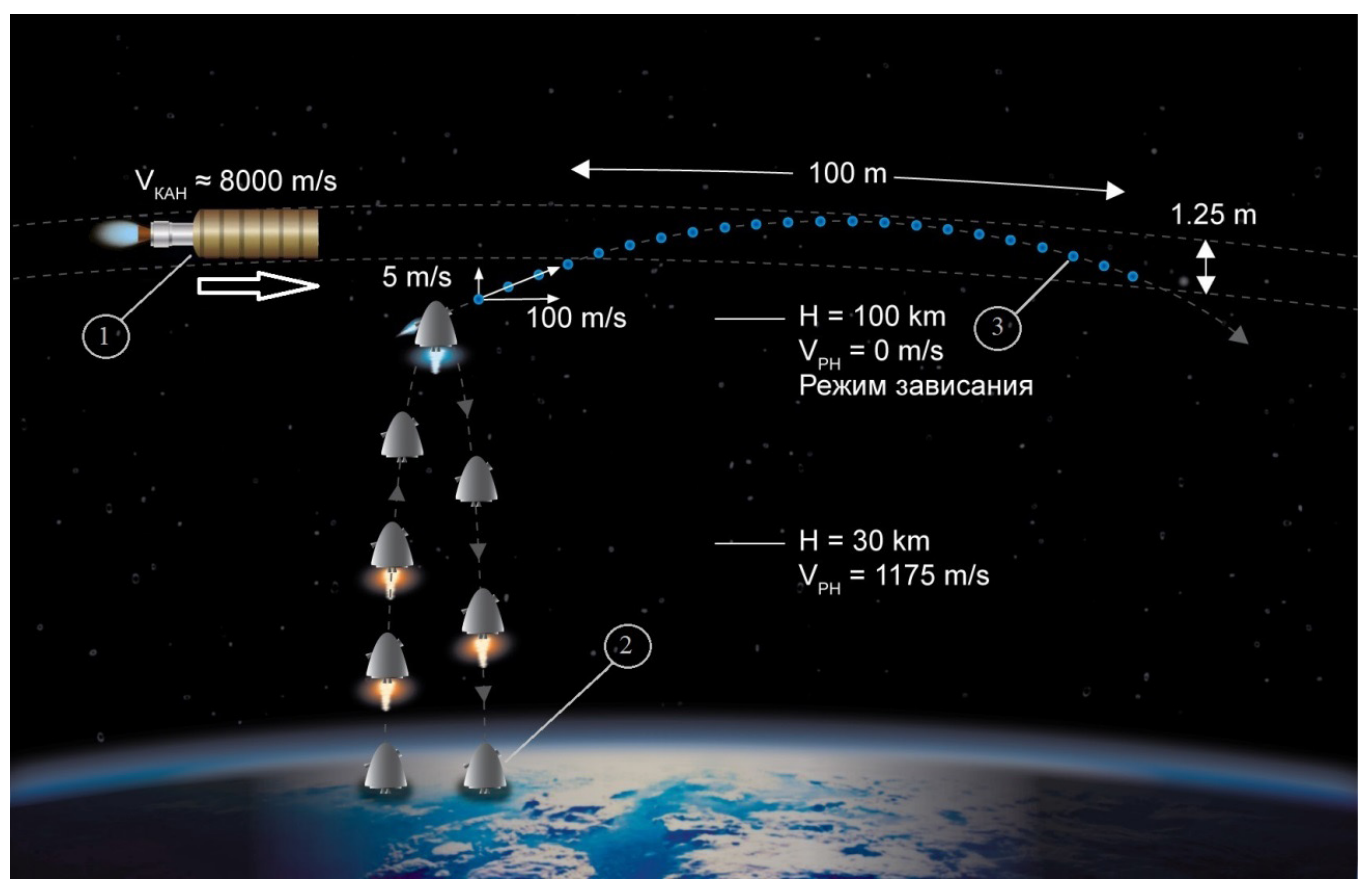

Рис. 9. Передача топлива из МСРН в точку встречи с околоземным орбитальным коллектором

1 - коллектор на НОО (ловушка грузов и межорбитальный буксир)

2 - МСРН с ЖРД «холодного типа»

3 - струя переохлажденной жидкости (шугообразный водород, метан и т.п.) или поток твердофазных частиц (углерод, литий, алюминий, титан и т.п.) либо капсул с жидкими веществами 


\section{Исследования космоса 1(6) • 2018}

Аналогичная схема поставок в орбитальный коллектор рассматривалась Э. Марвиком. Однако, из-за дискретного способа подачи больших порций груза, поднимаемых одной ракетой, масса околоземного коллектора должна составлять 40000 т. Это главный недостаток технологии Э. Марвика.

Околоземные коллекторы, создаваемые из недорогих лунных материалов, могут иметь массу тормозной среды меньшую, чем в концепции Э. Марвика, но, тем не менее, достаточно большую (с точки зрения современных возможностей), что позволяет перехватывать порции грузов массой в несколько тонн. На каждые 100 т массы тормозной среды из твердофазного алюминия коллектор без испарения среды поглощает порцию груза 1,28 т алюминия, на 100 т титана $-1,26$ т титана, на 100 т водяного льда - 1,06 т воды, на 100 т замороженного водорода - 0,37 т водорода (по другой схеме для поглощения водорода может использоваться литий, благодаря образованию гидрида лития). При эффективном теплоотводе за один год коллектор примет больше 11000 порций, и масса грузов превысит его массу на 2 порядка.

Увеличение порций перехватываемых грузов необходимо, потому что доставляются они суборбитальными ракетами носителями, для которых увеличение абсолютных размеров влечет сокращение удельных затрат на запуск.

Вместе с тем, при относительно небольшой высоте точки перехвата - 300 км и ниже, и повышенном рабочем ресурсе ракет, экономически эффективно могут применяться МСРН с малой грузоподъемностью. Аналогами таких ракет являются суборбитальные ракеты Р-1 и $\mathrm{V} 2$, «Викинг», «Аэроби». С учетом современного опыта создания многоразовых туристских суборбитальных и многоразовых первых ступеней ракет космического назначения могут быть созданы МСРН для обслуживания орбитального коллектора.

Возможные технико-экономические параметры МСРН:

- Стоимость-1,5-2 млн. долл.

- Межполетное обслуживание - 2 тыс. долл.

- Ресурс 1 - до 200 полетов (до 3,5 ч. работы ЖРД).
- $\quad$ Ресурс 2 - до 2400 полетов (до 40 ч. работы ЖРД).

- $\quad$ Ресурс 3 - до 6000 полетов (до 100 ч. работы ЖРД).

- Полезный груз - 50-100 кг.

Расчет цены доставки грузов в точку перехвата коллектором производится по приближенной формуле:

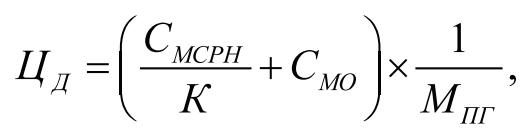

где $\breve{A}_{\mathcal{A}}$ - цена доставки в точку перехвата; $C_{\text {мсРн }}$ - стоимость МСРН; $K$ - количество пусков (ресурс ЖРД деленный на время работы ЖРД при пуске, равное 50-60 с); $M_{\text {мо }}$ - стоимость межполетного обслуживания; $M_{\Pi \Gamma}$ - масса полезного груза МСРН.

Расчет по формуле (2) дает следующие значения диапазона цен:

- Ц Цена доставки - 95-240 долл./кг (ресурс 1) плюс стоимость топлива.

- Ц Цена доставки - 26-57 долл./кг (ресурс 2) плюс стоимость топлива.

- Ц Цена доставки - 23-47 долл./кг (ресурс 3) плюс стоимость топлива.

Без учета стоимости топлива цена доставки сокращается до 23-240 долл./кг (средняя цена топлива - 0,4 долл./кг, удельный расход топлива зависит от типа МСРН).

Рабочий ресурс МСРН зависит от ресурса ракетных жидкостных двигателей, который может быть многократно повышен - суборбитальные ракеты не имеют жестких лимитов на удельные величины ЖРД и конструкции ракеты. Это значит, что в МСРН могут быть применены технические решения неприемлемые в РКН. К примеру, если запас прочности при проектировании камер некоторых типов ЖРД выбирают полуторным, а разрушающее давление - вдвое больше максимального рабочего давления, то камеры двигатели МСРН могут иметь более высокие коэффициенты запаса прочности. Вместо дорогой и ненадежной турбонасосной подачи топлива в ЖРД можно применить недорогую и надежную вытеснительную подачу. Корпус ракеты может быть выполнен из более тяжелых, но жаростойких сплавов, которые применяются как обшивочный материал для сверхзвуковых самолетов, что актуально для сохранения корпуса 


\section{Космонавтика}

во время прохождения плотных слоев атмосферы при посадке. Также ЖРД МСРН могут иметь меньшее давление в камере сгорания и меньшую температуру. Выбором низкокалорийного топлива, организацией горения при большом избытке одного из его компонентов и при сравнительно небольшом давлении в камере достигается низкая температура продуктов сгорания. Стенки камеры ЖРД выдерживают температуру порядка $1800^{\circ} \mathrm{C}$. При снижении температуры и давления до уровня типовых авиационных реактивных двигателей может быть обеспечен межремонтный назначенный ресурс аналогичный авиационному - около 1000 ч вместо нынешнего ресурса ЖРД - 3-4 ч.

Для удовлетворительного снижения цены доставки ресурс ЖРД МСНР в 1000 часов избыточен - как показывают расчеты достаточно 40-100 часов. На практике ресурс до 40 часам обеспечивают однокомпонентные гидразиновые ЖРД при температуре порядка $1000^{\circ} \mathrm{C}$. При этом удельный импульс составляет около 2300 м/с. Этого достаточно для обслуживания коллекторов на орбитах с точками перехвата на высотах 200-380 км, хотя для этого придется использовать двухступенчатую схему МСРН.

Близкие параметры обеспечивает ЖРД с двухкомпонентным низкокалорийным топливом, например, с горючим в виде $75 \%$ раствора этилового спирта и жидкого кислорода. ЖРД с кислородно-водородным топливом при избытке горючего может дать лучшие результаты из-за более низкой температуры в камере сгорания по сравнению с керосиновым и низкой средней молекулярной массой рабочего тела. Перспективен вариант МСРН с трехкомпонентными ЖРД - керосин-кислород-водород, метан-кислород-водород или керосин-кислород-вода, метан-кислородвода. Примером трехкомпонентного двигателя является российский ЖРД РД-701 [34].

Полная цена доставки грузов на околоземный орбитальный коллектор складывается не только из цены, зависящей от МСРН, но и от цены, определяемой амортизацией коллектора.

Для нахождения возможной цены, определяемой орбитальным коллектором, который сооружается за счет поставок с Земли, а не с Луны, воспользуемся идеализированной моделью и формулой (1). Груз поступает в коллектор дискретно, но можно усреднить поток вещества в ловушку и рассматривать модель с непрерывным потоком.

За один год коллектор с полуторачасовой орбитой совершит 5840 оборотов. На каждом витке в него 2 раза поступает порция груза массой по 50 кг каждая или 100 кг за 1 виток. Всего за год в коллектор поступит 584000 кг грузов, что аналогично потоку вещества равного 0,0185 кг/с со скоростью около 8000 м/с.

При использовании ЭРД с удельным импульсом 16000 м/с, на компенсацию торможения коллектора будет расходоваться половина аккумулированного вещества. Испускаемый ЭРД поток РТ равен 0,00926 кг/с. Скорость РТ - 16000 м/с, что позволяет определить мощность ЭРД.

Мощность ЭРД составит 1185 кВт, а при типичном КПД 50\% электрическая мощность будет равна 2370 кВт. Если цена фотоэлектрических преобразователей для космоса в период реализации будет такой же высокой как в настоящее время, то есть порядка 50 тыс. долл./кВт, то стоимость ЭДУ будет не меньше 119 млн. долл.

Масса фотоэлектрических преобразователей, ЭРД и холодильников-излучателей (ХИ) может быть оценена в 11 кг/кВт электрической мощности. Соответственно общая масса агрегатов округленно равна 26000 кг.

Масса ловушки с тормозной средой - 6000 кг.

Общая масса коллектора - 32000 кг.

Стоимость доставки коллектора на НОО при цене 5000 долл./кг - 160 млн. долл.

Стоимость изготовления при средней цене 5000 долл./кг - 160 млн. долл.

Общая стоимость коллектора с энергодвигательной установкой - 439 млн. долл.

После расхода РТ в ЭРД остаток накопленной массы равен 292000 кг (584000 кг/2), что при 10 годах рабочего ресурса дает общую массу грузов в 2920000 кг.

Деление общей стоимости на общую массу грузов дает цену доставки - 150 долл./кг.

К этой цене следует добавить цену доставки для МСРН - 23-240 долл./кг.

Общий результат, в диапазоне 173-390 долл./ кг удовлетворительный и стимулирующий развитие промышленного освоения космоса. Вместе с тем, он показывает, что использование лунных 


\section{Исследования космоса 1(6) • 2018}

ресурсов для создания коллектора предпочтительней. Поставки лунного сырья дают коллектору ускоряющий импульс порядка 3000 м/с х 1 кг. Этот импульс компенсирует тормозной импульс, возникающий при захвате коллектором порции груза с Земли массой 0,375 кг: 8000 м/с х 0,375 кг. При этой операции в коллекторе образуется 16,5 МДж теплоты на захваченные грузы общей массой 1,375 кг или 44 МДж в пересчете на 1 кг земных грузов.

В результате использования потока грузов с Луны прием грузов с Земли осуществляется без использования тяги ЭРД и питающих двигатели солнечных батарей. В конечном итоге, солнечная энергодвигательная установка (ЭДУ) участвует в работе коллектора, но участвует косвенно - в виде ЭДУ окололунного коллектора. Вывод грузов с Луны в космос требует в 20 раз меньше затрат энергии чем вывод с Земли. Таким образом, работа околоземного коллектора обеспечивается, по сути, даровой энергией, которая генерируется за счет перевода потенциальной энергии в кинетическую энергию при сбрасывании лунных грузов в гравитационную яму Земли.

Если из стоимости коллектора вычесть затраты на ЭДУ и учесть, что на каждый 1 кг массы грузов с Земли в коллектор поступает дополнительно 2,67 кг грузов с Луны, то цена аккумуляции земных грузов снизится до 30 долл./кг. Это значит, что даже для коммерческой деятельности в околоземном пространстве необходимы лунные ресурсы.

На этой стадии эксплуатации орбитальных коллекторов, благодаря радикальному сокращению затрат, преодолевается ценовой барьер, препятствующий превращению космонавтики в рентабельное направление промышленной деятельности.

\section{Заключение}

1. В настоящей статье рассмотрена логистика космических грузоперевозок с точки зрения устранения избыточных и лишних транспортных операций и нахождения оптимальных схем организации грузопотоков и формирующих их технических средств на базе достигнутого научно-технического уровня.
2. Применен метод «ТРИЗ»к анализу технического базиса космических грузоперевозок, что привело к разработке принципиально новой технологии (способов) доставки грузов на искусственные и естественные спутники Земли и Луны, других небесных тел - технологии Moontrap-Sattrap.

3. Разработанные технологии решают задачу понижения стоимости доступа к ресурсам космоса: на первом этапе реализации технологии Moontrap транспортные затраты при сооружении базы на Луне сокращаются в 3-4 раза, при реализации технологии Sattrap в 3-4 раз сокращается стоимость создания промышленного комплекса «лунная орбитальная станция - лунная база» (ЛОС-ЛБ). Обе технологии взаимодополняющие, но могут реализовываться независимо друг от друга. Применение технологий делает разработку ресурсов Луны равноценной с разработкой ресурсов околоземных астероидов.

4. Показаны коммерчески перспективные товары и услуги ЛОС-ЛБ для аэрокосмических компаний и других потребителей на Земле: средства возвращения с НОO последних ступеней РН и кинетические ударники для экологически безопасных экскавационных работ на Земле в больших масштабах.

5. Рассмотрены наиболее вероятные этапы развития технологии Sattrap - поэтапное создание на основе лунных ресурсов системы доставки грузов с Земли на ИСЗ и обмена между ИСЗ. Дано расчетное обоснование сокращения транспортных затрат до величин меньше 1 процента от современного уровня.

6. На основании выше изложенного делается вывод, что открытие первой лунной базы и ее промышленная эксплуатация для нужд Земли может состояться значительно раньше сроков, намеченных без учета указанных технических новаций. Речь идет о 3-5 годах.

7. Для реализации этой перспективы рекомендуется проведение НИОКР по рассмотренным технологиям. Следует принять во внимание, что значительная часть работ не требует проведения дорогостоящих экспериментов в космическом пространстве и может проводиться в наземных условиях. При этом не требуется разработка принципиально новых устройств и технологий - инновационный процесс по Moontrap-Sattrap - это в 
основном интеграция и адаптация известных и апробированных технических решений.

8. Для финансового обеспечения НИОКР предлагается создание государственно-частного партнерства с привлечением зарубежных инвесторов из стран БРИКС, как наиболее заинтересованных членов и кандидатов «косми- ческого клуба»в приобретении «прорывных технологий» для преодоления отставания от космических держав. Привлечение инвесторов из США и Евросоюза рекомендуется также в связи с патентами на технологии в США и ЕС и возможностью эксклюзивного оказания коммерческих транспортных услуг на рынках этих стран.

\section{Библиография}

1. Чижевский А. Теория космических эр //...Три, два, один! / Сост. В.К. Чантурия. М.: Советская Россия, 1989. 496 с.

2. Академик Анатолий Коротеев: «Ядерная энергетика способна обеспечить качественный скачок в развитии космонавтики» // Ракетная техника. 18 июля 2010. URL: http://rbase.new-factoria.ru/news/ akademik-a-s-koroteev-yadernaya-energetika-sposobna-obespechit-kachestvennyj-skachok-v-razvitiikosmonavtiki-2/ (дата обращения: 04.04.2018)

3. «Космонавт-испытатель Сергей Кричевский: Ракетный этап космической деятельности подходит к концу». 12 апреля 2013. URL: http://vm.ru/news/2013/04/12/kosmonavt-ispitatel-sergej-krichevskijraketnij-etap-kosmicheskoj-deyatelnosti-podhodit-k-kontsu-191808.html (дата обращения: 29.03.2018).

4. Краффт А. Эрике. Будущее космической индустрии: Пер с англ. - М.: Машиностроение, 1979.200 с.

5. Гэтланд К. и др. Космическая техника. Иллюстрированная энциклопедия. Пер. с англ. М.: Мир, 1986. 295 с.

6. Левантовский В.И. Механика космического полета в элементарном изложении. М. «Наука».1980. 512 c.

7. Marwik E.F. Extraterrestrial transportation apparatus and method. Patent No. US4775120, Oct. 4, 1988. URL: https://docs.google.com/viewer?url=patentimages.storage.googleapis.com/pdfs/US4775120.pdf (дата обращения: 29.03.2018).

8. Marwik E.F. Extraterrestrial transportation apparatus and metod. Patent No. US5199671. Apr. 6, 1993. URL: https://docs.google.com/viewer?url=patentimages.storage.googleapis.com/pdfs/US5199671.pdf (дата обращения: 29.03.2018).

9. Demetriades S.T. A Novel System For Space Flight Using A Propulsive Fluid Accumulator // Journal of the British Interplanetary Society. 1959. Vol 17. Р. 114-119.

10. Бурдаков В.П., Данилов Ю.И. Физические проблемы космической тяговой энергетики. М.: Атомиздат, 1969.

11. Jones C., Masse D., Glass C., Wilhite A., Walker M. PHARO - Propellant Harvesting of Atmospheric Resources in Orbit. IEEE Aerospace Conference, Big Sky, MT, March 2010. DOI: 10.1109/AER0.2010.5447034. URL: https://pdfs.semanticscholar.org/4dbd/b60bbdfd0706eab54de7c6e45264d5f4d8c9.pdf (дата обращения: 03.04.2018).

12. Космические солнечные электростанции - проблемы и перспективы: монография / Г.Г. Райкунов, В.А. Комков, В. К. Сысоев, В. М. Мельников; под ред. Г.Г. Райкунова. М.: РУДН, 2017. 282 с.

13. SрасеХ впервые удалось успешно посадить первую ступень ракеты Falcon 9 // РИА Новости. 22 декабря 2015. URL: https://ria.ru/tv_science/20151222/1346676231.html?inj=1 (дата обращения: 04.04.2018).

14. Ларионов В. Илон Маск уменьшил ракету для полета на Марс // Новости высоких технологий. Ні-News. ru. 26 июля 2017. URL: https://hi-news.ru/technology/ilon-mask-umenshil-raketu-dlya-polyota-na-mars. html (дата обращения: 04.04.2018).

15. Elon Musk. Becoming a Multiplanet Species [video]. 68th annual meeting of the International Astronautical Congress in Adelaide, Australia: SpaceX. URL: https://www.youtube.com/watch?v=tdUX3ypDVwI (дата обращения: 04.04.2018). 


\section{Исследования космоса 1(6) • 2018}

16. Уваров В. Б. 5 марта в Точке кипения Агентства стратегических инициатив состоялось очередное заседание Спейснет // Журнал «Крылья Родины» в социальных сетях. 7 марта 2018 г. Национальноавиационный портал KR-media. URL: http://kr-media.ru/news/kosmos/5-martav-tochke-kipeniya-agent stvastrategicheskikh-initsiativ-sostoyalosocherednoe-zasedanie-spey / (дата обращения 10.03.2018).

17. Mayboroda A. How to build a Moon base cheaply // ROOM. 2017. №1. C. 70-73.

18. Майборода А.О. Как создать лунную базу и орбитальную станцию на $80 \%$ дешевле // Воздушно-космическая сфера. 2018. №1. С. 22-31.

19. Чеберко И. Академик Галимов: «Нужно налаживать производство на Луне» // Известия. 29 ноября 2016. URL: https://iz.ru/news/648070 (дата обращения: 04.04.2018).

20. Ling Z. et al. Correlated compositional and mineralogical investigations at the Change-3 landing site // Nature Communications. 2015.No 6. DOI:10.1038/ncomms9880.

21. Майборода А. О. Лунная и инопланетная база - новые возможности создания и эксплуатации // Актуальные проблемы российской космонавтики: Труды XXXVII академических чтений по космонавтике. Москва, январь-февраль 2013 г. / Под общ. ред. А.К. Медведевой. - М.: Комиссия РАН по разработке научного наследия пионеров освоения космического пространства, 2013. С. 293-296.

22. В РКК «Энергия» разработан проект космического «челнока» для полетов на Луну с околоземной орбиты // Военное обозрение. 26 мая 2016. URL: https://topwar.ru/95832-v-rkk-energiya-razrabotan-proektkosmicheskogo-chelnoka-dlya-poletov-na-lunu-s-okolozemnoy-orbity.html (дата обращения: 10.04.2018).

23. Хамиц И.И., Филиппов И.М., Бурылов Л.С., Тененбаум С.М., Перфильев А.В., Гусак Д.И. Концепция космической транспортно-энергетической системы на основе солнечного межорбитального электроракетного буксира // Космическая техника и технологии. 2017. №1. C. 32-40. URL: https://www.energia. ru/ktt/archive/2017/01-2017/01-02.pdf (дата обращения: 08.04.2018).

24. Луна - шаг к технологиям освоения Солнечной системы / Под науч. ред. В.П. Легостаева и В.А. Лопоты. М.: РКК «Энергия». 2011. 584 с.

25. Фролов И.Э. Развитие мировых высокотехнологичных производств и космические рынки: сможет ли космонавтика стать новым глобальным нововведением? // Экономическая наука современной России. 2017. №4 (79). C.43-57. URL: http://www.space2010.ru/Frolov_2017.pdf (дата обращения: 08.04.2018).

26. Агеев В. П., Островский В. г. Магнитоплазмодинамический двигатель большой мощности непрерывного действия на литии // Известия РАН. Энергетика. 2007. №3. С. 82-95.

27. После даты необратимости ничто не остановит глобальное потепление // Коммерсант.ru. Наука. 21 апреля 2015. URL: https://www.kommersant.ru/doc/2718294 (дата обращения: 10.03.2018).

28. ПК0520627. Ядерные энергетические установки для космических аппаратов высокоорбитального базирования. См. в базе данных: Федеральный информационный фонд отечественных и иностранных каталогов на промышленную продукцию.. URL: http://промкаталог.рф (дата обращения: 04.04.2018).

29. Грек А. Взорвать по-мирному: Мы по взрывам - впереди планеты всей // Популярная механика. 2006. №12. URL: https://www.popmech.ru/madein-russia/5908-vzorvat-po-mirnomu-mypo-vzryvam-vperediplanety-vsey/ (дата обращения: 10.03.2018).

30. Каревский А.В., Кочетков С.А. и др. Результаты расчетных и экспериментальных исследований по тепловому аккумулятору солнечного теплового ракетного двигателя // Авиакосмическая техника и технология. 2017. №2. С. 44-52.

31. Коротеев А.С., Акимов В.Н., Архангельский Н.И., Попов С.А. Солнечные энергодвигательные установки - эффективный путь развития средств межорбитальной транспортировки // Известия РАН. Энергетика. 2004. №5. С. 46-57.

32. Агеев В.П., Островский В.Г. Магнитоплазмодинамический двигатель большой мощности непрерывного действия на литии // Известия РАН. Энергетика. 2007. №3. С.82-95.

33. Грибков А.С. Технология и энергозатраты для космического производства металлических рабочих тел ракетных двигателей // Известия РАН. Энергетика. 2009. №2. С. 112-117.

34. Губанов Б.И. Триумф и трагедия «Энергии»: размышления главного конструктора. Т. 3 «Энергия» - «Буран». Нижний Новгород: НИЭР, 1998. 


\section{Космонавтика}

\section{References (transliterated)}

1. Chizhevskij A. Teoriya kosmicheskih er //...Tri, dva, odin! / Sost. V.K. Chanturiya. M.: Sovetskaya Rossiya, 1989. $496 \mathrm{~s}$.

2. Akademik Anatolij Koroteev: «Yadernaya energetika sposobna obespechit’ kachestvennyj skachok v razvitii kosmonavtiki» // Raketnaya tekhnika. 18 iyulya 2010. URL: http://rbase.new-factoria.ru/news/akademika-s-koroteev-yadernaya-energetika-sposobna-obespechit-kachestvennyj-skachok-v-razvitii-kosmonavtiki-2/ (data obrashcheniya: 04.04.2018)

3. «Kosmonavt-ispytatel' Sergej Krichevskij: Raketnyj ehtap kosmicheskoj deyatel'nosti podhodit k koncu». 12 aprelya 2013. URL: http://vm.ru/news/2013/04/12/kosmonavt-ispitatel-sergej-krichevskij-raketnij-etapkosmicheskoj-deyatelnosti-podhodit-k-kontsu-191808.html (29.03.2018).

4. Krafft A. Erike. Budushchee kosmicheskoj industrii: Per s angl. - M.: Mashinostroenie, 1979. $200 \mathrm{~s}$.

5. Gehtland K. i dr. Kosmicheskaya tekhnika. Illyustrirovannaya ehnciklopediya. Per. s angl. M.: Mir, 1986. $295 \mathrm{~s}$.

6. Levantovskij V.I. Mekhanika kosmicheskogo poleta v ehlementarnom izlozhenii. M. «Nauka».1980.512 s

7. Marwik E.F. Extraterrestrial transportation apparatus and metod. Patent No. US4775120, Oct. 4, 1988. URL: https://docs.google.com/viewer?url=patentimages. storage.googleapis.com/pdfs/US4775120.pdf (29.03.2018).

8. Marwik E.F. Extraterrestrial transportation apparatus and method. Patent No. US5199671. Apr. 6, 1993. URL: https://docs.google.com/viewer?url=patentimages.storage.googleapis.com/pdfs/US5199671.pdf (29.03.2018).

9. Demetriades S.T. A Novel System For Space Flight Using A Propulsive Fluid Accumulator // Journal of the British Interplanetary Society. 1959. Vol 17. P. 114-119.

10. Burdakov V.P., Danilov Yu.I. Fizicheskie problemy kosmicheskoj tyagovoj ehnergetiki. M.: Atomizdat, 1969.

11. Jones C., Masse D., Glass C., Wilhite A., Walker M. PHARO - Propellant Harvesting of Atmospheric Resources in Orbit. IEEE Aerospace Conference, Big Sky, MT, March 2010. DOI: 10.1109/AER0.2010.5447034. URL: https:// pdfs.semanticscholar.org/4dbd/b60bbdfd0706eab54de7c6e45264d5f4d8c9.pdf (03.04.2018).

12. Kosmicheskie solnechnye ehlektrostancii - problemy i perspektivy: monografiya / G.G. Rajkunov, V. A. Komkov, V. K. Sysoev, V. M. Mel'nikov; pod red. G. G. Rajkunova. M.: RUDN, 2017. 282 s.

13. SpaceX vpervye udalos' uspeshno posadit' pervuyu stupen' rakety Falcon 9 // RIA Novosti. 22 dekabrya 2015. URL: https://ria.ru/tv_science/20151222/1346676231.html?inj=1 (04.04.2018).

14. Larionov V. Ilon Mask umen'shil raketu dlya polyota na Mars // Novosti vysokih tekhnologij. Hi-News.ru. 26 iyulya 2017. URL: https://hi-news.ru/technology/ilon-mask-umenshil-raketu-dlya-polyota-na-mars.html (04.04.2018).

15. Elon Musk. Becoming a Multiplanet Species [video]. 68th annual meeting of the International Astronautical Congress in Adelaide, Australia: SpaceX. URL: https://www.youtube.com/watch?v=tdUX3ypDVwI (04.04.2018).

16. Uvarov V. B. 5 marta v Tochke kipeniya Agentstva strategicheskih iniciativ sostoyalos' ocherednoe zasedanie Spejsnet. // Zhurnal «Kryl'ya Rodiny» v social'nyh setyah. 7 marta 2018 g. Nacional'no-aviacionnyj portal KR-media. URL: http://kr-media.ru/news/kosmos/5-marta-v-tochkekipeniya-agentstva-strategicheskikhinitsiativ-sostoyalos-ocherednoe-zasedaniespey/ (10.03.2018).

17. Mayboroda A. How to build a Moon base cheaply // ROOM. 2017. №1. Pp. 70-73.

18. Mayboroda A.O. Kak sozdat' lunnuyu bazu i orbital'nuyu stanciyu na $80 \%$ deshevle // Vozdushno-kosmicheskaya sfera. 2018. №1. S. 22-31.

19. Cheberko I. Akademik Galimov: «Nuzhno nalazhivat' proizvodstvo na Lune» // Izvestiya. 29 noyabrya 2016. URL: https://iz.ru/news/648070 (04.04.2018).

20. Ling Z. et al. Correlated compositional and mineralogical investigations at the Change-3 landing site // Nature Communications. 2015.No 6. DOI:10.1038/ncomms9880. 


\section{Исследования космоса 1(6) • 2018}

21. Mayboroda A. O. Lunnaya i inoplanetnaya baza - novye vozmozhnosti sozdaniya i ehkspluatacii //Aktual'nye problemy rossijskoj kosmonavtiki: Trudy XXXVII akademicheskih chtenij po kosmonavtike. Moskva, yanvar'fevral' 2013 g. / Pod obshch. red. A.K. Medvedevoj. - M.: Komissiya RAN po razrabotke nauchnogo naslediya pionerov osvoeniya kosmicheskogo prostranstva, 2013. S. 293-296.

22. VRKK «Energiya» razrabotan proekt kosmicheskogo «chelnoka» dlya polyotov na Lunu s okolozemnoj orbity // Voennoe obozrenie. 26 maya 2016. URL: https://topwar.ru/95832-v-rkk-energiya-razrabotan-proekt-kosmicheskogo-chelnoka-dlya-poletov-na-lunu-s-okolozemnoy-orbity.html (10.04.2018).

23. Hamic I.I., Filippov I.M., Burylov L.S., Tenenbaum S.M., Perfil'ev A.V., Gusak D.I. Koncepciya kosmicheskoj transportno-ehnergeticheskoj sistemy na osnove solnechnogo mezhorbital'nogo ehlektroraketnogo buksira // Kosmicheskaya tekhnika i tekhnologii. 2017. №1. S. 32-40. URL: https://www.energia.ru/ktt/archive/2017/012017/01-02.pdf (08.04.2018).

24. Luna - shag k tekhnologiyam osvoeniya Solnechnoj sistemy / Pod nauch. red. V.P. Legostaeva i V.A. Lopoty. M.: RKK «Energiya». 2011. $584 \mathrm{~s}$.

25. Frolov I.EH. Razvitie mirovyh vysokotekhnologichnyh proizvodstv i kosmicheskie rynki: smozhet li kosmonavtika stat' novym global'nym novovvedeniem? // Ekonomicheskaya nauka sovremennoj Rossii. 2017. №4 (79). S.43-57. URL: http://www.space2010.ru/Frolov_2017.pdf (08.04.2018).

26. Ageev V. P., Ostrovskij V. G. Magnitoplazmodinamicheskij dvigatel' bol'shoj moshchnosti nepreryvnogo dejstviya na litii // Izvestiya RAN. Energetika. 2007. №3. S. 82-95.

27. Posle daty neobratimosti nichto ne ostanovit global'noe poteplenie // Kommersant.ru. Nauka. 21 aprelya 2015. URL: https://www.kommersant.ru/doc/2718294 (10.03.2018).

28. PK0520627. YAdernye ehnergeticheskie ustanovki dlya kosmicheskih apparatov vysokoorbital'nogo bazirovaniya. Sm. v baze dannyh: Federal'nyj informacionnyj fond otechestvennyh i inostrannyh katalogov na promyshlennuyu produkciyu. URL: http://промкаталог.pф (04.04.2018).

29. Grek A. Vzorvat' po-mirnomu: My po vzryvam - vperedi planety vsej // Populyarnaya mekhanika. 2006. №12. URL: https://www.popmech.ru/madein-russia/5908-vzorvat-po-mirnomu-mypo-vzryvam-vperediplanety-vsey/ (10.03.2018).

30. Karevskij A.V., Kochetkov S.A. i dr. Rezul'taty raschetnyh i ehksperimental'nyh issledovanij po teplovomu akkumulyatoru solnechnogo teplovogo raketnogo dvigatelya // Aviakosmicheskaya tekhnika i tekhnologiya. 2017. №2. S. 44-52.

31. Koroteev A.S., Akimov V.N., Arhangel'skij N.I., Popov S.A. Solnechnye ehnergodvigatel'nye ustanovki - ehffektivnyj put' razvitiya sredstv mezhorbital'noj transportirovki // Izvestiya RAN. Energetika. 2004. №5. S. 46-57.

32. Ageev V.P., Ostrovskij V.G. Magnitoplazmodinamicheskij dvigatel' bol'shoj moshchnosti nepreryvnogo dejstviya na litii // Izvestiya RAN. Energetika. 2007. №3. S.82-95.

33. Gribkov A.C. Tekhnologiya i ehnergozatraty dlya kosmicheskogo proizvodstva metallicheskih rabochih tel raketnyh dvigatelej // Izvestiya RAN. Energetika. 2009. №2. S. 112-117.

34. Gubanov B.I. Triumf i tragediya «Energii»: razmyshleniya glavnogo konstruktora. T. 3 «Energiya» - «Buran». Nizhnij Novgorod: NIEHR, 1998. 